\title{
Electrodialysis in Aqueous-Organic Mixtures
}

Sandra. E. Kentisha*, Elanor Kloester ${ }^{a}$, Geoff W. Stevens ${ }^{a}$, Colin A. Scholes ${ }^{a}$, Ludovic

Dumée $e^{a, b}$

${ }^{a} \mathrm{CRC}$ for Greenhouse Gas Technologies(CO2CRC), Department of Chemical and

Biomolecular Engineering, The University of Melbourne, Parkville, Vic. 3010 Australia.

${ }^{b}$ Present Address: Institute for Frontier Materials, Deakin University, Locked Bag 20000, Geelong, Vic. 3220 Australia.

*Corresponding Author: sandraek@unimelb.edu.au

Keywords: electrodialysis, hydro-organic solvents, diffusion, swelling, ion exchange membranes 


\section{ABSTRACT}

This review investigates the effects of hydro-organic solvents on ion exchange membranes used in conventional electrodialysis. The thermodynamics of electrodialysis is first presented in relation to operation in purely aqueous solutions, where the Donnan potential describes the equilibrium partitioning at the membrane/solvent interface. The mass transfer kinetics through the membrane are described using the Nernst-Planck equation; while concentration polarization describes the mass transfer resistance in the solution boundary layer. Each of these relationships is found to change significantly as the organic concentration in the solvent is increased and the system consequently deviates from ideality. The extent of membrane swelling in these mixed solvents is also critical, as it determines the diffusion coefficient of both ionic and nonionic species within the membrane structure. 


\section{Introduction}

Electrodialysis (ED) was first made possible with the development of semipermeable membranes at the end of the $19^{\text {th }}$ century, but was not used industrially on a large scale until the late 1950 's, when it was used for the desalination of brackish water. The technique was quickly recognised to be both efficient and cost effective and has remained a popular technology for desalination, currently representing $3.6 \%$ of total worldwide installed capacity, treating 2.5 million $\mathrm{m}^{3} /$ day of water in total(1). Advances in electrodialysis, particularly with regards to ion exchange membrane technology and modes of operation, have greatly improved over the years and consequently the industrial applications of electrodialysis have significantly expanded (2). Today electrodialysis is a well-proven technology that is used worldwide and is expected to continue developing across numerous industries for varying applications into the future (3).

Electrodialysis is a diverse term which includes many different modes of operation. All modes, however, involve alternating ion-exchange membranes within an ionic solvent, bounded by an anode and a cathode to supply a direct current through the system (4). This current provides an electric potential driving force in opposing directions for the anions and cations within the solvent. The alternating arrangements of the permselective membranes consequently create channels which are either ion rich (concentrate streams) or ion poor (diluate streams) (2). An example of a conventional electrodialysis configuration is shown in Figure 1. In commercial applications several hundreds of cell pairs are assembled in a stack between the two electrodes. 
Over the years new operational modes have been found to advance the areas in which electrodialysis could be used; often through lowering the cost of operation or by increasing process efficiency to achieve higher purity levels. Electrodialysis reversal (EDR) is one example. During EDR operation, the direction of current is reversed periodically to dissolve calcium carbonate or calcium sulfate scale which otherwise would form deposits on the surface of the membrane(5). Further examples of advancement through altered modes of operation include continuous electrodeionisation (EDI) which allows for complete deionisation of water by altering the conventional configuration to include mixed-bed ionexchange resin throughout the entire diluate channel; and electrodialysis with bipolar membranes (EDBM) which permits the conversion of organic salts into commercial scale acids or bases $(4,6-8)$. The development of the configurations mentioned here are just some examples of how electrodialysis has been able to evolve to enter new fields and areas for application.

To date, the major application for ED is the desalination and treatment of brackish and sea water $(9,10)$. It is less sensitive to fouling compared to RO and so is also used at a small scale for the treatment of industrial wastewater $(11,12)$, to reclaim water from the petroleum or metal production (13-15) and as a purification technique for cooling tower make-up effluents $(16,17)$. However, given the ability of electrodialysis to purify a solvent mixture without changing the organic concentration, electrodialysis is becoming increasingly popular within the food, beverage and pharmaceutical industries(18-21). Operations within these industries rarely involve purely aqueous solutions but frequently rely on organic solvents. The effect of organic solvents on electrodialysis is not well documented to date but increasingly represents a larger portion of the available applications $(22,23)$. 
Applications for electrodialysis can be simplified into two categories: electrolyte reduction, which aims to purify the solvent and in which the diluate channel is the product stream; and electrolyte recovery, in which the concentrate channel is the product stream(7). Industrial uses which recover the electrolytes still mainly use aqueous solvents. However, a significant example where organics are present is the recovery of organic acids from fermentation broths $(4,22,24-28)$ which can use both standard electrodialysis for acid recovery and bipolar membranes to convert salts such as lactate into the corresponding acid. A similar approach can be used to both concentrate monoethanoalamine salts(29) or convert them into the corresponding organic base (30) and to recover organic acids from cyclohexanone-based waste solutions (28). Similarly, bipolar membranes can be used to generate sodium methoxide from a solution of sodium acetate in methanol (31). Electrodialysis has also been considered for the recovery of bioactive peptides from milk (32), alfalfa (33) or soy protein hydrolysates(34).

Applications involving electrolyte reduction from an organic solution are more common and include fruit juice de-acidification and demineralisation (35), tartrate stabilisation of wine(36, 37), dairy whey demineralisation (38) or immunoglobulin removal from blood plasma $(39,40)$. A recent application is the removal of heat stable salts from the amine solvents used in acid gas treatment and carbon capture (41-43). In this case, the solvent is a mixture of 20 to $30 \mathrm{wt} \%$ of an alkanolamine such as monoethanolamine, piperazine or methyldiethanolamine and the salts requiring removal can be alkanolamine sulphates, nitrates or low molecular weight organic anions such as formate or acetate. These salts can also be removed through the use of bipolar membranes, which convert salts such as alkanolamine sulfates $(\mathrm{RH})_{2} \mathrm{SO}_{4}$ into the corresponding alkanolamine $(\mathrm{R})$ and acid $\left(\mathrm{H}_{2} \mathrm{SO}_{4}\right)(43,44)$. A 
further case is the removal of sulphate and chloride from $70 \mathrm{wt} \%$ ethylene glycol in water during the production of sodium carbonate (45).

These examples demonstrate the importance of understanding the effects of mixed solvents on the operational process of electrodialysis. By understanding the changes to the process, optimisation in each industry can be performed to minimise operational costs and to maximise commercial value.

Comprehensive reviews of the theory and application of ED in aqueous solutions $(4,10,21$, $46,47)$ and of the structure of ion exchange membranes(48) have been published and this paper does not intend to cover these areas in detail. However, to place this review in context, it is first necessary to present an overview of the ion exchange membranes used and the thermodynamic theory that underpins the ED approach.

\section{Ion-Exchange Membranes}

Ion exchange membranes (IEMs) are the key components to effective electrodialysis operation. IEMs are dense, non-porous membranes and the drivers and physical equations which determine their performance differ greatly from the porous type membranes used in ultrafiltration or microfiltration processes. The material chemistry, rather than pore size or distribution, determines the membrane performance; with mass transport and separation being achieved through differences in solubility, conductivity and diffusivity(49).

All ion-exchange membranes consist of a polymer matrix containing either positive or negative fixed charge groups which allow the passage of mobile counterions (ions with the opposite charge as the fixed ions) through the membrane, while preventing the passage of

mobile coions (ions with the same charge as the fixed ions)(2). This structure creates a 
selectively permeable material which conducts electricity and is the basis of electrodialysis operation.

Ion-exchange membranes are traditionally categorised into anion exchange membranes (AEMs) or cation exchange membranes (CEMs) based on the charge of the fixed ionic groups which are attached to the membrane matrix. These two membrane types, however, can be further categorised based upon the polymeric backbone materials used and the structure of formation. In many cases, the polymer backbone consists of aromatic hydrocarbon rings, such as chloromethlystyrene-divinylbenzene (50). For example, the Neosepta ${ }^{\circledR}$ construction consists of sulfonic groups grafted to a structure of divinylbenzene reticulated polystyrene (PS) and polyvinylchloride (PVC). Some zones in the polymer are densely packed crystalline PVC regions which are not permeable to ions or water and act as effective crosslinks. The sulfonic functional groups and their corresponding counterions are found in areas of amorphous PVC and PS (51). Transport in such membranes relies on swelling in the ionised zones due to uptake of water, making the zones more voluminous and less numerous until a threshold of percolation is met, which allows a continuous ionic junction between the two membrane surfaces and hence makes electrical conduction and ion separation possible (52).

A linear fluorocarbon polymer backbone can also be used for CEM manufacture. The most commonly used commercial membrane of this type is Nafion $117^{\circledR}$ which consists of a tetrafluoroethylene (Teflon) and perfluorinated vinylether copolymer with terminal sulfonate groups on a side chain. The Teflon forms crystalline areas and the vinylether forms amorphous areas which contained the fixed functional groups. Although Nafion is mechanically strong, it is not cross-linked and the size of the ionic cluster can vary strongly with different solvents and counterions (52).

The majority of practically-used and commercial ion exchange membranes are homogenous (47), where charged groups are chemically bonded to the polymer matrix. 
Common functional groups are sulfonic acid groups $\left(-\mathrm{SO}_{3}{ }^{-}\right)$for $\mathrm{CEMs}$ and quaternary ammonium groups $\left(-\mathrm{NH}_{4}{ }^{+}\right)$for AEMs. Despite their name, these ion exchange groups do not exist homogenously throughout the membrane but rather form microdomains; the frequency and density of which has an effect on the physiochemical and resilience properties of each membrane (53).

A smaller proportion is heterogeneous membranes, in which the charged groups are instead physically bound as an ion exchange resin mixed in with the membrane during synthesis (54). The original membranes from Ionics Inc. (now part of GE Water and Process Technologies) are examples of heterogeneous membranes. Some commonly used and commercially available IEMs are shown in Tables 1 and 2, with others available from Fujifilm and Asahi Chemical (Aciplex). 
Table 1 A selection of cation exchange membranes available for electrodialysis applications (data from suppliers, (2) and (48)). Membranes are homogeneous except where noted.

\begin{tabular}{|c|c|c|c|c|c|c|c|c|c|}
\hline $\begin{array}{l}\text { Manufacturer } \\
\text { and } \quad \text { Trade } \\
\text { Name }\end{array}$ & Code & $\begin{array}{l}\text { Electrical } \\
\text { Resistance* } \\
\left(\mathrm{ohm} / \mathrm{cm}^{2}\right)\end{array}$ & $\begin{array}{l}\text { Thickness } \\
\text { (micron) }\end{array}$ & $\begin{array}{l}\text { Ion-exchange } \\
\text { capacity } \\
\text { (meq/g) }\end{array}$ & $\begin{array}{l}\text { Water } \\
\text { Uptake } \\
(\text { wt \%) }\end{array}$ & $\begin{array}{l}\text { Permselectivity } \\
(\%)^{* *}\end{array}$ & Structure & Applications & References \\
\hline \multirow{3}{*}{$\begin{array}{l}\text { Fumatech } \\
\text { Fumasep }\end{array}$} & FKS & $<8$ & 120 & 1.0 & $12-15$ & 96 & & & \\
\hline & FKB & $<4$ & 90 & $0.9-1.0$ & 15 & 98 & & Bipolar ED & $(4,44)$ \\
\hline & FKL & $<4$ & 115 & 0.6 & 10 & 92 & & Alkali recovery & \\
\hline \multirow[t]{3}{*}{$\begin{array}{l}\text { Astom } \\
\text { Neosepta }\end{array}$} & CMX & 3.0 & 170 & $1.5-1.8$ & $25-30$ & 97 & $\mathrm{PS} / \mathrm{PVC} / \mathrm{DVB}$ & $\begin{array}{c}\text { Demineralisation of whey, sucrose, } \\
\text { groundwater } \\
\text { Purification and concentration of } \\
\text { organics }\end{array}$ & $(55-58)$ \\
\hline & CIMS & 1.8 & 150 & $2.2-2.5$ & $30-35$ & 98 & & Deacidification of metal solutions & $(59,60)$ \\
\hline & CMB & 4.5 & 210 & $2.4-2.7$ & $37-42$ & & & Alkali Recovery & $(61,62)$ \\
\hline \multirow[t]{5}{*}{ AGC Selemion } & CMV & 3.0 & 120 & 2.4 & 25 & 96 & PS/DVB & Heavy metal ion removal & $(63)$ \\
\hline & CMD & 17 & 380 & & & 94 & Heterogeneous & & (64) \\
\hline & $\mathrm{HSF}$ & 19 & 150 & & & & $\begin{array}{c}\text { Double layer, } \\
\text { PFSA } \\
\end{array}$ & Proton selective & $(65,66)$ \\
\hline & $\mathrm{CSO}$ & 2.3 & 100 & & & 97 & $\begin{array}{c}\text { PS/DVB } \\
\text { Surfactant coated }\end{array}$ & Monovalent ion selective & (64) \\
\hline & CMF & 2.5 & 440 & & & 95 & PFSA & High durability & $(66)$ \\
\hline Dupont Nafion & 117 & 1.5 & 180 & 0.90 & 16 & 97 & PFSA & & $(52)$ \\
\hline Sybron Ionac & $\begin{array}{l}\text { MC- } \\
3470\end{array}$ & 10 & 380 & & $30-35$ & 75 & $\begin{array}{l}\text { Heterogeneous, } \\
\text { PS/DVB }\end{array}$ & & $(67)$ \\
\hline $\begin{array}{l}\text { Membranes } \\
\text { International }\end{array}$ & $\begin{array}{l}\text { CMI- } \\
7000\end{array}$ & $<30$ & 450 & 1.6 & & 94 & $\begin{array}{c}\text { Heterogeneous, } \\
\text { PS/DVB }\end{array}$ & & $(68,69)$ \\
\hline
\end{tabular}

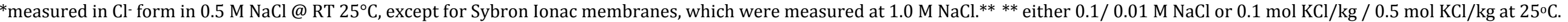

$\mathrm{PS}=$ polystyrene, $\mathrm{DVB}=$ divinylbenzene, $\mathrm{PFSA}=$ perfluourosulfonic acid polymer 
Table 2 A selection of anion exchange membranes available for electrodialysis applications (data from suppliers, Strathmann 2004 and Nagarale,2006). Membranes are homogeneous except where noted.

\begin{tabular}{|c|c|c|c|c|c|c|c|c|c|}
\hline $\begin{array}{l}\text { Manufacturer } \\
\text { and Trade Name }\end{array}$ & Code & $\begin{array}{c}\text { Electrical } \\
\text { Resistance* } \\
\left(\mathrm{ohm} / \mathrm{cm}^{2}\right)\end{array}$ & $\begin{array}{l}\text { Thickness } \\
\text { (micron) }\end{array}$ & $\begin{array}{c}\text { Ion-exchange } \\
\text { capacity } \\
\text { (meq/g) }\end{array}$ & $\begin{array}{l}\text { Water } \\
\text { Uptake }\end{array}$ & $\begin{array}{l}\text { Permselectivity } \\
(\%)^{* *}\end{array}$ & Structure & Applications & Refs. \\
\hline \multirow{4}{*}{$\begin{array}{l}\text { Fumatech } \\
\text { Fumasep }\end{array}$} & FAB & $<1$ & 115 & 1.3 & 20 & 96 & & Bipolar ED & $(4,44)$ \\
\hline & $\begin{array}{c}\text { FAA- } \\
3\end{array}$ & 0.66 & $50-55$ & 2.0 & 64 & 96.6 & $\begin{array}{l}\text { Quaternary } \\
\text { ammonium } \\
\text { hydroxide } \\
\text { polymer }\end{array}$ & Strong Alkali solutions & $(70,71)$ \\
\hline & FAP & $<1$ & 60 & & 30.4 & 92 & & Strong Acid Solutions, oxidant resistant & $(72)$ \\
\hline & FAD & $<1$ & 90 & 1.5 & 25 & 91 & & Diffusion Dialysis for Acid Recovery & $(58,73)$ \\
\hline \multirow[t]{5}{*}{$\begin{array}{l}\text { Astom } \\
\text { Neosepta }\end{array}$} & AMX & 2.4 & 140 & $1.4-1.7$ & $25-30$ & 95 & PS/DVB & $\begin{array}{c}\text { Whey Demineralisation, } \\
\text { Organic purification }\end{array}$ & $\begin{array}{l}(55,56) \\
(57,58)\end{array}$ \\
\hline & AHA & 4.1 & 220 & $0.5-3.0$ & $13-20$ & & $\begin{array}{l}\text { Polyethylene } \\
(50-70 \%) \text { and } \\
\text { trimethyl } \\
\text { ammonio } \\
\text { methyl (30- } \\
50 \%)\end{array}$ & Alkali Removal & $(74)$ \\
\hline & $\mathrm{ACM}$ & 2.6 & 110 & $1.0-1.5$ & 15 & & PS/DVB & Acid Recovery & $(30,75)$ \\
\hline & $\mathrm{ACS}$ & 3.8 & 130 & & & & & $\begin{array}{l}\text { Purification and desalination of organics } \\
\text { Nitrate removal }\end{array}$ & $(59)$ \\
\hline & AFN & 0.5 & 160 & $2.3-3.5$ & $40-55$ & & & Demineralisation of organics & $(74,76)$ \\
\hline \multirow[t]{6}{*}{ AGC Selemion } & AMV & 2.8 & 120 & 1.9 & 19 & 96 & $\mathrm{PS} / \mathrm{PVC} / \mathrm{DVB}$ & & $(77)$ \\
\hline & DSV & 1.1 & 100 & 2.3 & $18-20$ & 92 & & & $(76)$ \\
\hline & AAV & 6.4 & 120 & 0.95 & $20-25$ & 95 & & Acid recovery & $(75)$ \\
\hline & ASV & 3.7 & 120 & & $20-25$ & 97 & $\begin{array}{l}\mathrm{PS} / \mathrm{DVB} \text {, dual } \\
\text { layer }\end{array}$ & Monovalent ion selective & $\begin{array}{l}(78) \\
(79)\end{array}$ \\
\hline & $\mathrm{AHO}$ & 20 & 300 & & & 95 & & High temperature and oxidant proof & \\
\hline & APS4 & 0.70 & 150 & & & & & Oxidant proof & \\
\hline \multirow[t]{2}{*}{ Sybron Ionac } & $\begin{array}{l}\text { MA- } \\
3475\end{array}$ & 25 & 406 & 0.9 & $30-32$ & 80 & PS/DVB & & $\begin{array}{c}(28,67, \\
80)\end{array}$ \\
\hline & $\begin{array}{l}\text { MA- } \\
7500 \\
\end{array}$ & 10 & 460 & 1.1 & & & $\begin{array}{l}\text { Heterogeneous } \\
\text { PS/DVB }\end{array}$ & & $(80)$ \\
\hline $\begin{array}{l}\text { Membranes } \\
\text { International }\end{array}$ & $\begin{array}{l}\text { AMI - } \\
7001\end{array}$ & $<40$ & 450 & 1.3 & & 90 & $\begin{array}{c}\text { Heterogeneous } \\
\text { PS/DVB }\end{array}$ & & $(68,69)$ \\
\hline
\end{tabular}

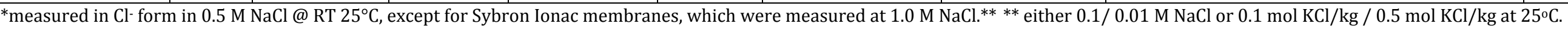

$\mathrm{PS}=$ polystyrene $\mathrm{DVB}=$ divinylbenzene, $\mathrm{PFSA}=$ perfluourosulfonic acid polymer 


\section{Ion Exchange Theory}

The performance of electrodialysis systems is determined by the transport rates of different ionic components in the membrane and in the adjacent bulk solution. Mass transfer in electrolyte solutions is driven by gradients in electrochemical potential but must overcome the frictional and electrochemical resistances of the ion-exchange membranes (2). As electrodialysis necessitates the use of IEMs, transport is additionally affected by the presence of the fixed charge in the membranes. Ionic transport through electrodialysis systems is therefore based on two principles: the Nernst-Planck equation which dictates the kinetics; and the Donnan partition coefficient which dictates the equilibrium boundary conditions (81).

The Donnan partition coefficient is based on the fact that at the interface between the solution and membrane phases, the chemical potentials must be equal(81). The coefficient quantifies the relationship between the concentration of the species (i) in the solution $\left(C_{i}\right)$ with that in the membrane phase $\left(c_{i}\right)(81)$ :

$$
\frac{C_{i}}{c_{i}}=\exp \left(\frac{z_{i} F E_{d o n}}{R T}\right)
$$

where the Donnan potential $\left(E_{d o n}\right)$ is a function of the fixed charges within the membrane, $z_{i}$ is the charge of the ionic species, $\mathrm{F}$ is the Faraday constant $(96487 \mathrm{C} / \mathrm{mol})$, $\mathrm{R}$ is the universal gas constant $(8.314 \mathrm{~J} / \mathrm{mol} . \mathrm{K})$ and $\mathrm{T}$ is the temperature. This equation shows that if the concentration in the bulk solution is low and the concentration of the fixed charges in the membrane is high then Donnan exclusion is very effective. Specifically, it is this equilibria that dictates that cations will not be transmitted through an AEM and anions do not flow through a CEM. This is referred to as the permselectivity or the transport number of the membrane. 
The Nernst-Planck equation describes the rate of transport of species across the membrane, affected by both a concentration difference and an electrical potential difference:

$$
j_{i}=J_{v} K_{i c} c_{i}-D_{i} \frac{d c_{i}}{d x}-Z_{i} D_{i} c_{i} \frac{F}{R T} \frac{d \psi}{d x}
$$

where $\mathrm{J}_{\mathrm{i}}$ is the flux of any species (i) through the membrane, $\mathrm{c}_{\mathrm{i}}$ is the species concentration within the membrane, and $\mathrm{x}$ is distance. The first term relates to the convection or coupling of solute transport with the flow of bulk solvent $\left(\mathrm{J}_{\mathrm{v}}\right)$ across the membrane with $\mathrm{K}_{\mathrm{ic}}$ as the convective hindrance factor and $\mathrm{c}_{\mathrm{i}}$ as the solute concentration. This term can usually be ignored in electrodialysis systems. The second term represents diffusional mass transfer based on Fick's Law where $D_{i}$ is the Fickian diffusion coefficient and $\mathrm{x}$ is the distance across the membrane. Again, for most ions in aqueous solution, this term can be ignored.

The third term is usually most dominant for ionic species and represents the migration of ions due to ionic conductance, with $\mathrm{F}$ as the Faraday constant and $\psi$ as the electrical potential. This term suggests that by increasing the voltage across the stack, the ionic flux will increase linearly. However in reality the flux increase tails off as current increases, due to increasing mass transfer resistance in the boundary layer of the fluid adjacent to the membrane. This is referred to as concentration polarization. Under these circumstances, the overall mass transfer coefficient for each ion is determined by the sum of two resistances: a resistance related to the ion diffusion through the membrane, as given by Equation 2, and a resistance related to the mass transfer from the solution bulk to the membrane (82). Eventually, a limiting current density $\mathrm{I}_{\text {lim. }}$ is reached, where this boundary layer resistance dominates and at this point, the current density stabilizes (2)(Figure 2).

However, as the voltage is increased further, the current density increases again. This is referred to as the overlimiting region and can be attributed to either electro-convection or 
water splitting (83). Electro-convection refers to microscale fluid flows that develop within the depleted boundary layer due to electro-osmotic effects $(84,85)$. Conversely, water splitting refers to the dissociation of water to provide ions that can carry the charge at the membrane surface, as at the limiting current density, this charge falls to zero. Water splitting generally occurs more readily on the anion exchange membrane than the cation one (86).

\section{The Effect of Mixed Solvents on Equilibrium Thermodynamics}

In mixed aqueous/organic solvents, the Donnan potential, and subsequently the transport number, can be affected by changes to the solubility of many salts. A decrease in solubility will result in fewer mobile charges being available per unit volume of mixed solvent present (45). As an example, the solubility of carbonate ions was shown to decline in $70 \mathrm{wt} \%$ ethylene glycol relative to water (45). In such situations, the conductivity and therefore the limiting current density are significantly lower than in an aqueous solution. Further, the reduced number of ions can lead to an increased electrical resistance within the membrane material. Indeed, it has been shown that the electrical resistance of ED membranes increases exponentially for ionic concentrations less than $0.1 \mathrm{M} \mathrm{NaCl}(0.6 \mathrm{wt} \%$ or $6000 \mathrm{ppm})$ (58). Such low concentrations are common in mixed solvents. The reduced solubility can also lead to increased fouling at the membrane surface as ionic species precipitate more readily. Further, as the ionic strength increases, 'salting out' of proteins or phase separation into separate organic and aqueous phases can occur (solvent demixing). Conversely, the solubility of organic acids, such as salicylic and octanoic acids increase in ethanol/water mixtures (22), which can be used to advantage in an electrodialysis operation.

Many workers have also observed that the changes in the solvent composition can cause changes in the selectivity of the membrane for specific ions. Both Sata et al $(50,87)$ and Gärtner et al. (45) found that more strongly hydrated ions permeate more readily through a membrane in contact with an ethylene glycol or diethylene glycol solution than with water, 
although the cause of this change in selectivity is less clear. Similarly, the flux of $\mathrm{H}^{+}$is observed to increase relative to the flux of $\mathrm{Na}^{+}$through a Neosepta CMX cation exchange membrane as the proportion of ethanol or methanol in alcohol/water mixtures increases $(22$, $88)$.

\section{The Effect of Mixed Solvents on Mass Transfer Kinetics}

When operating electrodialysis in systems with organics, the system is no longer able to be considered as an ideal solution. In such situations, the activity coefficient, $\gamma_{\mathrm{i}} \neq 1$ and therefore the activity, $a_{i} \neq C_{i}$. Further, diffusion of ions can no longer be described using the usual binary component Fickian approach (the second term in Equation 2). Rather, the driving forces $\left(\mathrm{X}_{\mathrm{i}}\right)$ acting on any ion $i$ are equal to the sum of the friction forces between the component and all other components in the system:

$$
X_{i}=\sum_{k} \frac{R T}{\bigoplus_{\mathrm{i}} C_{i}}\left(\mathrm{v}_{\mathrm{i}}-\mathrm{v}_{\mathrm{k}}\right)
$$

where $\bigoplus_{i}$ is referred to as the Stefan Maxwell diffusion coefficient and $v$ is the linear velocity of the component. In turn, the driving forces can be related to the sum of the electrical potential $(\psi)$ and the chemical potential $(\eta)$. Assuming convective effects are minimal, this leads to (2):

$$
\mathrm{J}_{\mathrm{i}}=-\mathrm{Ð}_{\mathrm{i}}\left(1+\mathrm{c}_{\mathrm{i}} \frac{d \ln \gamma_{i}}{d C_{i}}\right) \frac{d c_{i}}{d x}-\bigoplus_{\mathrm{i}} \frac{z_{i} C_{i} F}{R T} \frac{d \psi}{d x}
$$

From this equation it can be seen that the activity coefficient will strongly affect the diffusion term of this flux equation, and the nature of the multicomponent system will additionally affect the electrical migration term through the change in diffusion coefficient. Despite this apparent importance, neither Stefan Maxwell diffusion or the activity coefficient 
are often considered or discussed in ED applications, with the notable exception of some workers $(26,45,89,90)$.

It is more common to account for the effects of mixed solvents through the use of experiments to investigate singular properties such as electrical resistance or membrane selectivity. However, the prediction of activity coefficients is possible with the use of activity models such as the Pitzer equations(91)and the Non-Random Two-Liquid (NRTL) model (92) and the increasing availability of simulation packages means that this approach is increasingly viable.

For organic solvents, transport through the membrane by concentration dependent diffusion (the first term in Equation (4)) can be significant. For example, Figure 3 shows the permeation of glycerol in a fermentation broth through IEMs via diffusional mechanisms (24). This diffusional permeation is also a function of temperature, as indicated by Figure 4.

While electrical effects are is usually dominant for charged species, there are also some cases where the concentration dependent diffusion term is significant. For example, Wang and co-workers (28) relate the low current efficiency values obtained in their experiments with an Ionac MA-3475 AEM at high applied potential to back diffusion of organic anions from the concentrate to the diluate solution. That is, under these conditions, the concentration difference between these two solutions is sufficiently high for such diffusion to play a role. However, the high permselectivity of other IEMs usually means that diffusion of ions is negligible relative to the electrical potential migration term. 
The mass transport of ions can also be affected by the viscosity of the solvent, as this affects the boundary layer resistance and hence the extent of concentration polarization. An increasing viscosity will lead to greater concentration polarization and hence a lower limiting current density.

\section{Membrane Swelling}

The extent of membrane swelling due to solvent uptake has a direct effect on the mass transfer resistance of the membrane and consequently on the migration of ions, recorded as an increase in electrical resistance (7). Similarly membrane swelling directly affects the mechanical stability of the membrane. The desirable amount of swelling often must be a balance between achieving both these outcomes. By understanding the effects of organics and mixed solvents on membrane swelling, a good and balanced compromise on qualities can more easily be found (48).

The percentage of water taken up into the membrane generally decreases as the proportion of water present in a mixed solvent decreases and this gives rise to an increase in electrical resistance. As an example, Gärtner et al. (45) record a membrane resistance of between 2 and $15 \mathrm{ohm} . \mathrm{cm}^{2}$ in aqueous solution for a range of six membranes but in $70 \mathrm{wt} \%$ ethylene glycol this resistance increases by an order of magnitude to 30 to $110 \mathrm{ohm} . \mathrm{cm}^{2}$. Similarly, Innocent et al. (88) observe substantial increases in electrical resistance in a solution of $\mathrm{N}$ methylformamide (see Figure 5) due to reducing water content. Sarrazin (93) noted that greater resistance was observed with acetic acid and acetonitrile than with methanol and ethanol.

Mixed solvents however, result in greater total solvent uptake into the membrane, since the water will be absorbed into the hydrophilic functional regions, while the non-polar organics will be absorbed into the hydrophobic polymer lattice. Unlike purely aqueous solvents which 
cannot penetrate the hydrophobic regions of the membrane, mixed solvents will cause the membrane to swell in all directions, potentially causing a loss in membrane stability. The extent of this swelling increases with temperature (94) and decreases with the extent of crystallinity within the polymer (95).

For example, Gärtner et al. (45) found that the swelling in a range of membranes observed in aqueous solutions of sodium carbonate and in $70 \mathrm{wt} \%$ ethylene glycol was essentially additive, so that the swelling in a solution of $0.1 \mathrm{M} \mathrm{Na}_{2} \mathrm{CO}_{3}$ in $70 \mathrm{wt} \%$ ethylene glycol caused greater swelling than either of the individual cases (Figure 6). A similar result was found when the swelling of Neosepta ${ }^{\circledR}$ was investigated using a methanol-water solvent mixture (Figure $7 \mathrm{a},(52)$ ). The membrane thickness increases with increasing methanol concentration until it reached a maximum at around 50\% methanol concentration. In this case, the authors argue that Neosepta is highly crosslinked and that as the methanol concentration increases further, the constrained morphology begins to force water out of the ionised functional sites and back into the bulk solution, causing the membrane to shrink in size. As the water exits the membrane structure the active ionised zones shrink and the membrane loses thickness in addition to conductivity (Figure $7 \mathrm{~b}$ ). Eventually the ionised zones become disconnected and the membrane falls below the threshold of percolation (52). This effectively limits any conductivity and prevents any further separation of ions. The extent of swelling is also a function of the ionic concentration (lithium chloride), with greater swelling at the lowest concentration. This probably reflects osmotic pressure effects at higher concentrations which will tend to force water from the membrane. A similar dependence upon ionic strength has been observed by Randová and co-workers (96)with methanol/water solutions in Nafion 112. 
Nafion is known to swell more than other ion exchange membranes in the presence of organic solvents $(23,97)$. In methanol-water and isopropanol-water systems, similar behaviour to that described above is usually observed (Figure 8). The membrane initially swells, but this swelling peaks at around 50-70 vol\% alcohol before falling again (98-101). Conversely, Chaabane et al. (52) observe a continuous increase in thickness in a methanolwater system and relates this to the lack of crosslinks within the membrane structure. These differences may reflect differences in the pre-treatment of the Nafion membranes prior to use. These authors did not boil the membrane in water or acid prior to use. This boiling pretreatment expands the structure (102) and reduces the solvent capacity but is usually necessary to ensure reproducibility of results (101).

As the membrane swells, the diffusion coefficient for the alcohol generally increaseas. Significant permeation of methanol and ethanol has been observed in such systems $(23,101$, 103). The increase in methanol permeability is weaker when salts are present in the solution (103). Figure 9 summarises how the average diffusion coefficient can vary in a Nafion membrane as a function of the feed solution composition for an isopropanol water mixture.

Cabasso et al. (104) argue that water and isopropanol both move through the same hydrophilic water channels in Nafion, as evidenced by similar activation energies for permeation $(\mathrm{E}=4.7-4.9 \mathrm{kcal} / \mathrm{mol}$, see Figure 4). Conversely, the activation energy for isopropranol permeation in a sulfonated polyethylene membrane was much higher (20 $\mathrm{kcal} / \mathrm{mol}$ ) (105), suggesting that in this latter case, the isopropanol permeated through the amorphous, non-ionic polyethylene matrix via a conventional solution-diffusion mechanism $(105)$.

Ethève et al. (106) find that the type of swelling in Nafion also depends upon the nature of the organic co-solvent. While behaviour similar to that described above was observed for 
Nafion in tetrahydrofuran (THF), quite different behaviour was observed for ethylene glycol and N-methylformamide solutions (Figure 10). These authors argued that the hydrophobic part of the THF molecules was located in the perfluorinated chains while the hydrophilic part interacted with the water molecules contained in the clusters. The THF thus acts to separate the hydrophobic polymeric chains, consequently allowing a higher water uptake. Gebel et al. (94) argues that the Donor Number of the organic solvent is the most relevant number for determining the extent of solvent related swelling, with a swelling maxima occurring at around $\mathrm{DN}=25-30 \mathrm{kcal} \mathrm{mol}^{-1}$ for all mixed solvents.

In pure organic solvents, Doyle et al. (107) also found a strong relationship between the degree of swelling and the ionic conductivity for Nafion membranes. Solvents with functional groups such as alcohols, amides and sulfoxide gave strong swelling and highly conductive films, with hydrogen bonding solvents faring especially well. Poor conductivities resulted from functional groups such as nitriles, cyclic or linear ethers and carbonates.

A number of authors $(94,98,108-110)$ conclude that cation solvation is the driving force for swelling of the hydrophilic regions in Nafion 117 and relate this to the solvated volume of the cationic species. The increase in swelling and total water uptake follows the sequence $\mathrm{H}^{+}>\mathrm{Li}^{+}>\mathrm{Na}^{+}>\mathrm{K}^{+}>\mathrm{Cs}^{+}$, reflecting the strength of hydration of the cations. Randova et al. (96) observe a similar trend in methanol/water mixtures. Tuan et al. $(111,112)$ similarly show that the water content of Neosepta CMS and CMV cation-exchange membranes is greater in the $\mathrm{H}^{+}$form $(27-29 \%)$ than in the $\mathrm{Na}^{+}$form $(20-24 \%)$. Iwai and Yamanishi (113) observe similar trends - the total water content increases in Nafion 117CS for aqueous solutions of trivalent $\left(\mathrm{Al}^{3+}\right)>$ divalent $\left(\mathrm{Mg}^{2+}>\mathrm{Ca}^{2+}\right)>$ monovalent $\left(\mathrm{Li}^{+}>\mathrm{Na}^{+}>\mathrm{K}^{+}\right)$ cations reflecting their greater hydration number. Conversely, other workers (110) find that the uptake of acetontrile or methanol into Nafion 117 is independent of the cation, confirming 
that it is the uptake of water that is a function of the cation size, rather than the organic solvent.

Galier et al.(114) observe an opposing relationship between the cation size and the permeation of neutral saccharides. Specifically, the permeability of saccharides increases as the electrolyte solutions is changed in the order of $\mathrm{NH}_{4} \mathrm{Cl}>\mathrm{NaCl}>\mathrm{CaCl}_{2}>\mathrm{MgCl}_{2}$ for a Neosepta CMX membrane (Figure 11). This trend is opposite to that observed for the swelling of the membrane in such solutions as discussed above. These authors point out that the total water content consists of both the 'bound' water of hydration and the 'free' solvent. It is the free solvent content that has most influence on the permeation of neutral solutes. While swelling and water content generally increase with the hydration of the counter-ion, the free water content decreases (104).

\section{Conclusions}

This paper has summarised the alterations in both the physical properties, the physiochemical characteristics and the mass transfer kinetics of ion exchange membranes used in electrodialysis when organics are present in the solvent.

The core differences when considering the mass transfer kinetics of the system are that ideal solutions can no longer be assumed and that a constant diffusion coefficient can no longer be utilised. Hence simple relationships do not apply for the determination of parameters such as the limiting current density. Similarly, values for the activity coefficients are required for concentration related parameters. The activity coefficient was not found to be widely discussed within currently published research papers. 
The extent of membrane swelling has a direct impact on the mechanical strength of the membrane and upon the diffusion coefficient of ions, measured as the electrical resistance. The swelling behaviour is strongly dependent upon membrane structure and the extent of crosslinking. Ion exchange membranes generally experience a maximum swelling point as the proportion of organics increases but this then falls due to internal pressures and shrinkage of ionic zones. However, in some cases, a continuous increase in swelling is observed across the full range of solvent composition.

As the applicability of electrodialysis in systems with organics is expected to continue to expand over the coming decades, it is vital that investigatory work on the effects of organics on various commercial IEMs continues. Future work should aim to utilise activity models to further understand the kinetics and thermodynamic of electrodialysis operation under nonideal conditions. Similarly, investigation into the general effects of organics of a specific polarity on membrane swelling is necessary.

\section{Acknowledgements}

The authors wish to acknowledge financial assistance provided to the CO2CRC by the Australian Government through its CRC program and through Australian National Low Emissions Coal Research and Development (ANLEC R\&D). ANLEC R\&D is supported by Australian Coal Association Low Emissions Technology Limited and the Australian Government through the Clean Energy Initiative. 


\section{References}

1. Intelligence, G. W. What Technologies are Used? http://www.desalination.com/market/technologies

2. Strathman, H., Ion-exchange membrane separation processes. In Membrane science and technology series, Heiner, S., Ed. Elsevier: 2004; Vol. 9.

3. Shaposhnik, V. A.; Kesore, K. (1997) An early history of electrodialysis with permselective membranes. Journal of Membrane Science 136: 35-39.

4. Huang, C.; Xu, T.; Yang, X. (2007) Regenerating fuel-gas desulfurizing agents by using bipolar membrane electrodialysis (BMED): effect of molecular structure of alkanolamines on the regeneration performance. Environ. Sci. Technol. 41: 984-989.

5. Katz, W. E. (1979) The electrodialysis reversal (EDR) process. Desalination 28: 3140.

6. Bailly, M. (2002) Production of organic acids by bipolar electrodialysis: realizations and perspectives. Desalination 144: 157-162.

7. Farrell, S.; Hesketh, R. P.; Slater, C. S. (2003) Exploring the potential of electrodialysis. Chemical engineering education 37: 52.

8. Persson, A.; Garde, A.; Jönsson, A.-S.; Jonsson, G.; Zacchi, G. (2001) Conversion of sodium lactate to lactic acid with water-splitting electrodialysis. Applied Biochemistry and Biotechnology 94: 197-211.

9. Ryabtsev, A. D.; Kotsupalo, N. P.; Titarenko, V. I.; Igumenov, I. K.; Gelfond, N. V.; Fedotova, N. E.; Morozova, N. B.; Shipachev, V. A.; Tibilov, A. S. (2001) Development of a two-stage electrodialysis set-up for economical desalination of sea-type artesian and surface waters. Desalination 137: 207-214.

10. Strathmann, H. (2010) Electrodialysis, a mature technology with a multitude of new applications. Desalination 264: 268-288.

11. Chao, Y.-M.; Liang, T. M. (2008) A feasibility study of industrial wastewater recovery using electrodialysis reversal. Desalination 221: 433-439.

12. Nataraj, S. K.; Sridhar, S.; Shaikha, I. N.; Reddy, D. S.; Aminabhavi, T. M. (2007) Membrane-based microfiltration/electrodialysis hybrid process for the treatment of paper industry wastewater. Separation and Purification Technology 57: 185-192.

13. Chen, S.-S.; Li, C.-W.; Hsu, H.-D.; Lee, P.-C.; Chang, Y.-M.; Yang, C.-H. (2009) Concentration and purification of chromate from electroplating wastewater by two-stage electrodialysis processes. Journal of Hazardous Materials 161: 1075-1080.

14. Marder, L.; Bernardes, A. M.; Zoppas Ferreira, J. (2004) Cadmium electroplating wastewater treatment using a laboratory-scale electrodialysis system. Separation and Purification Technology 37: 247-255.

15. Rao, J. R.; Prasad, B. G. S.; Narasimhan, V.; Ramasami, T.; Shah, P. R.; Khan, A. A. (1989) Electrodialysis in the recovery and reuse of chromium from industrial effluents. Journal of Membrane Science 46: 215-224.

16. Osantowski, R.; Kane, J. (1984) Control solids in cooling water to cut makeup requirements. Power 128: 35-6.

17. Jordan, D. R.; Bearden, M. D.; McIlhenny, W. F. (1975) Blowdown concentration by electrodialysis. Chem. Eng. Prog. 71: 77-82. 
18. Bazinet, L.; Firdaous, L. (2011) Recent patented applications of ion-exchange membranes in the agri-food sector. Recent Pat. Chem. Eng. 4: 207-216.

19. Fidaleo, M.; Moresi, M. (2006) Electrodialysis applications in the food industry. Advanced Food and Nutrition Research 51: 265-360.

20. Girard, B.; Fukumoto, L. R. (2000) Membrane processing of fruit juices and beverages: a review. Crit. Rev. Biotechnol. 20: 109-175.

21. Xu, T.; Huang, C. (2008) Electrodialysis-based separation technologies: a critical review. AIChE J. 54: 3147-3159.

22. Kameche, M.; Xu, F.; Innocent, C.; Pourcelly, G. (2003) Electrodialysis in waterethanol solutions: Application to the acidification of organic salts. Desalination 154: 9-15.

23. Xu, F.; Innocent, C.; Pourcelly, G. (2005) Electrodialysis with ion exchange membranes in organic media. Separation and Purification Technology 43: 17-24.

24. Cheryan, M.; Parekh, S. R. (1995) Separation of glycerol and organic acids in model ethanol stillage by electrodialysis and precipitation. Process Biochemistry 30: 17-23.

25. Datta, R.; Henry, M. (2006) Lactic acid recovery from fermentation broth using onestage electrodialysis. Journal of Chemical Technology and Biotechnology 81: 1119- 1129.

26. Fidaleo, M.; Moresi, M. (2013) Concentration of trisodium citrate by electrodialysis. Journal of Membrane Science 447: 376-386.

27. Kim, Y. H.; Moon, S.-Y. (2001) Lactic acid recovery from fermentation broth using one-stage electrodialysis. Journal of Chemical Technology and Biotechnology 76: 169-178.

28. Wang, Z.; Luo, Y.; Yu, P. (2006) Recovery of organic acids from waste salt solutions derived from the manufacture of cyclohexanone by electrodialysis. Journal of Membrane Science 280: 134-137.

29. de Groot, M. T.; Bos, A. A. C. M.; Lázaro, A. P.; de Rooij, R. M.; Bargeman, G. (2011) Electrodialysis for the concentration of ethanolamine salts. Journal of Membrane Science 371: 75-83.

30. de Groot, M. T.; de Rooij, R. M.; Bos, A. A. C. M.; Bargeman, G. (2011) Bipolar membrane electrodialysis for the alkalinization of ethanolamine salts. Journal of Membrane Science 378: 415-424.

31. Sridhar, S. (1996) Electrodialysis in a non-aqueous medium: production of sodium methoxide. Journal of Membrane Science 113: 73-79.

32. Poulin, J. F.; Amiot, J.; Bazinet, L. (2007) Improved peptide fractionation by electrodialysis with ultrafiltration membrane: Influence of ultrafiltration membrane stacking and electrical field strength. Journal of Membrane Science 299: 83-90.

33. Firdaous, L.; Dhulster, P.; Amiot, J.; Gaudreau, A.; Lecouturier, D.; Kapel, R.; Lutin, F.; Vézina, L. P.; Bazinet, L. (2009) Concentration and selective separation of bioactive peptides from an alfalfa white protein hydrolysate by electrodialysis with ultrafiltration membranes. Journal of Membrane Science 329: 60-67.

34. Langevin, M. E.; Bazinet, L. (2011) Ion-exchange membrane fouling by peptides: A phenomenon governed by electrostatic interactions. Journal of Membrane Science 369: 359366.

35. Rai, P.; De, S. In Membrane-based separation process for juice processing, 2012; CRC Press: 2012; pp 213-230. 
36. Lasanta, C.; Gomez, J. (2012) Tartrate stabilization of wines. Trends Food Sci. Technol. 28: 52-59.

37. Norberta, d. P. M. In Membrane processes in must and wine industries, 2010; WileyVCH Verlag GmbH \& Co. KGaA: 2010; pp 105-118.

38. Bazinet, L. (2005) Electrodialytic phenomena and their applications in the dairy industry: a review. Crit. Rev. Food Sci. Nutr. 45: 307-326.

39. Bing, D. H.; DiDonno, A. C.; Regan, M.; Strang, C. J. (1986) Blood plasma processing by electrodialysis. Bioprocess Technol. 1: 135-60.

40. Nifong, T. P.; Gerhard, G. S. (2002) Separation of IgG and IgM from Albumin in Citrated Human Plasma Using Electrodialysis and Metal Ion Affinity Precipitation. ASAIO J. 48: 645-649.

41. Dumée, L.; Scholes, C.; Stevens, G.; Kentish, S. (2012) Purification of aqueous amine solvents used in post combustion $\mathrm{CO} 2$ capture: A review. International Journal of Greenhouse Gas Control 10: 443-455.

42. Meng, H.; Zhang, S.; Li, C.; Li, L. (2008) Removal of heat stable salts from aqueous solutions of $\mathrm{N}$-methyldiethanolamine using a specially designed three-compartment configuration electrodialyzer. Journal of Membrane Science 322: 436-440.

43. Huang, C.; Xu, T. (2006) Comparative study on the regeneration of flue-gas desulfurizing agents by using conventional electrodialysis (ED) and biopolar membrane electrodialysis (BMED). Environ. Sci. Technol. 40: 5527-5531.

44. Huang, C.; Xu, T.; Zhang, Y.; Xue, Y.; Chen, G. (2007) Application of electrodialysis to the production of organic acids: State-of-the-art and recent developments. Journal of Membrane Science 288: 1-12.

45. Gärtner, R. S.; Wilhelm, F. G.; Witkamp, G. J.; Wessling, M. (2005) Regeneration of mixed solvent by electrodialysis: selective removal of chloride and sulfate. Journal of Membrane Science 250: 113-133.

46. Strathmann, H. In Fundamentals in electromembrane separation processes, 2009; Wiley-VCH Verlag GmbH \& Co. KGaA: 2009; pp 83-119.

47. $\mathrm{Xu}, \mathrm{T}$. (2005) Ion exchange membranes: State of their development and perspective. Journal of Membrane Science 263: 1-29.

48. Nagarale, R. K.; Gohil, G. S.; Shahi, V. K. (2006) Recent developments on ionexchange membranes and electro-membrane processes. Advances in Colloid and Interface Science 119: 97-130.

49. Wang, L. K.; Chen, J. P.; Hung, Y.; Shammus, N. K., Membrane and desalination technologies. Human Press: New York, The USA, 2011; Vol. 13.

50. Sata, T.; Mine, K.; Matsusaki, K. (1998) Change in Transport Properties of AnionExchange Membranes in the Presence of Ethylene Glycols in Electrodialysis. Journal of Colloid and Interface Science 202: 348-358.

51. Goering, R. M.; Bowman, C. N.; Koval, C. A.; Noble, R. D.; Williamson, D. L. (1998) Role of ion-exchange membrane morphology and sorption properties in facilitated transport di-olefin/mono-olefin separations. Journal of Membrane Science 144: 133-143.

52. Chaabane, L.; Bulvestre, G.; Innocent, C.; Pourcelly, G.; Auclair, B. (2006) Physicochemical characterization of ion-exchange membranes in water-methanol mixtures. European Polymer Journal 42: 1403-1416. 
53. Sata, T., Ion exchange membranes: preparation, characterization, modification and application. The Royal Society of Chemistry: Cambridge, UK, 2004.

54. Volodina, E.; Pismenskaya, N.; Nikonenko, V.; Larchet, C.; Pourcelly, G. (2005) Ion transfer across ion-exchange membranes with homogeneous and heterogeneous surfaces. Journal of Colloid and Interface Science 285: 247-258.

55. Ghalloussi, R.; Garcia-Vasquez, W.; Chaabane, L.; Dammak, L.; Larchet, C.; Bellakhal, N. (2012) Decline of ion-exchange membranes after utilization in electrodialysis for food applications. Physical \& Chemical News 65: 66-72.

56. Lee, H.-J.; Ahn, S. J.; Seo, Y.-J.; Lee, J.-W. (2013) A feasibility study on the multistage process for the oxalic acid pretreatment of a lignocellulosic biomass using electrodialysis. Bioresour. Technol. 130: 211-217.

57. Zhang, X.; Li, C.; Wang, Y.; Luo, J.; Xu, T. (2011) Recovery of acetic acid from simulated acetaldehyde wastewaters: Bipolar membrane electrodialysis processes and membrane selection. J. Membr. Sci. 379: 184-190.

58. Długołęcki, P.; Anet, B.; Metz, S. J.; Nijmeijer, K.; Wessling, M. (2010) Transport limitations in ion exchange membranes at low salt concentrations. Journal of Membrane Science 346: 163-171.

59. Casas, S.; Aladjem, C.; Cortina, J. L.; Larrotcha, E.; Cremades, L. V. (2012) Seawater Reverse Osmosis Brines as a New Salt Source for the Chlor-Alkali Industry: Integration of $\mathrm{NaCl}$ Concentration by Electrodialysis. Solvent Extraction and Ion Exchange 30: 322-332.

60. Tanaka, Y. (2011) Ion-Exchange Membrane Electrodialysis for Saline Water Desalination and Its Application to Seawater Concentration. Industrial \& Engineering Chemistry Research 50: 7494-7503.

61. Ben Ali, M. A.; Rakib, M.; Laborie, S.; Viers, P.; Durand, G. (2004) Coupling of bipolar membrane electrodialysis and ammonia stripping for direct treatment of wastewaters containing ammonium nitrate. J. Membr. Sci. 244: 89-96.

62. Habova, V.; Melzoch, K.; Rychtera, M.; Sekavova, B. (2004) Electrodialysis as a useful technique for lactic acid separation from a model solution and a fermentation broth. Desalination 162: 361-372.

63. Tuan, L. X.; Buess-Herman, C.; Hurwitz, H. D. (2008) Absorption equilibrium and permselectivity of cation exchange membranes in sulfuric acid, sodium chloride and nickel sulfate media. J. Membr. Sci. 323: 288-298.

64. Iizuka, A.; Hashimoto, K.; Nagasawa, H.; Kumagai, K.; Yanagisawa, Y.; Yamasaki, A. (2012) Carbon dioxide recovery from carbonate solutions using bipolar membrane electrodialysis. Separation and Purification Technology 101: 49-59.

65. Pupkevich, V.; Glibin, V.; Karamanev, D. (2007) The effect of ferric ions on the conductivity of various types of polymer cation exchange membranes. J. Solid State Electrochem. 11: 1429-1434.

66. Anelli, P. L.; Viscardi, C. F.; Delogu, P.; Goffredi, F.; Nardelli, A.; Giovenzana, G. B. Process for the preparation of a iodinating agent. WO2011003894A1, 2011.

67. Karabacakoglu, B.; Tezakil, F.; Guvenc, A. (2014) Removal of hardness by electrodialysis using homogeneous and heterogeneous ion exchange membranes. Desalin. Water Treat. Ahead of Print. 
68. Mehanna, M.; Kiely, P. D.; Call, D. F.; Logan, B. E. (2010) Microbial Electrodialysis Cell for Simultaneous Water Desalination and Hydrogen Gas Production. Environ. Sci. Technol. 44: 9578-9583.

69. Xiao, L.; Young, E. B.; Berges, J. A.; He, Z. (2012) Integrated PhotoBioelectrochemical System for Contaminants Removal and Bioenergy Production. Environ. Sci. Technol. 46: 11459-11466.

70. Santasalo-Aarnio, A.; Hietala, S.; Rauhala, T.; Kallio, T. (2011) In and ex situ characterization of an anion-exchange membrane for alkaline direct methanol fuel cell (ADMFC). J. Power Sources 196: 6153-6159.

71. Carmo, M.; Doubek, G.; Sekol, R. C.; Linardi, M.; Taylor, A. D. (2013) Development and electrochemical studies of membrane electrode assemblies for polymer electrolyte alkaline fuel cells using FAA membrane and ionomer. J. Power Sources 230: 169-175.

72. Frenzel, I.; Holdik, H.; Stamatialis, D. F.; Pourcelly, G.; Wessling, M. (2005) Chromic acid recovery by electro-electrodialysis I. Evaluation of anion-exchange membrane. J. Membr. Sci. 261: 49-57.

73. Veerman, J.; de Jong, R. M.; Saakes, M.; Metz, S. J.; Harmsen, G. J. (2009) Reverse electrodialysis: Comparison of six commercial membrane pairs on the thermodynamic efficiency and power density. J. Membr. Sci. 343: 7-15.

74. Durmaz, F.; Kara, H.; Cengeloglu, Y.; Ersoz, M. (2005) Fluoride removal by Donnan dialysis with anion exchange membranes. Desalination 177: 51-57.

75. Pourcelly, G.; Tugas, I.; Gavach, C. (1994) Electrotransport of sulphuric acid in special anion exchange membranes for the recovery of acids. Journal of Membrane Science 97: 99-107.

76. Narěbska, A.; Staniszewski, M. (1997) Separation of Fermentation Products by Membrane Techniques. I. Separation of Lactic Acid/Lactates by Diffusion Dialysis. Separation Science and Technology 32: 1669-1682.

77. Le, X. T. (2013) Contribution to the study of properties of Selemion AMV anionexchange membranes in acidic media. Electrochimica Acta 108: 232-240.

78. Lu, H.-Y.; Lin, C.-S.; Lee, S.-C.; Ku, M.-H.; Hsu, J.-P.; Tseng, S.-J.; Lin, S.-H. (2011) Preparation of mineral source water from deep sea water: Reduction of sulfate ion using selemion ASV membrane. AIChE J. 57: 1033-1042.

79. Rapp, H.-J.; Pfromm, P. H. (1998) Electrodialysis for chloride removal from the chemical recovery cycle of a kraft pulp mill. J. Membr. Sci. 146: 249-261.

80. Davis, S. M.; Gray, G. E.; Kohl, P. A. (2008) Candidate membranes for the electrochemical salt-splitting of sodium sulfate. J. Appl. Electrochem. 38: 777-783.

81. Mulder, M., Basic Principles of Membrane Technology. 2 ed.; Kluwer Academic Publishers: Dordrecht, The Netherlands, 1996; p 458-458.

82. Hasson, D.; Beck, A.; Fingerman, F.; Tachman, C.; Shemer, H.; Semiat, R. (2014) Simple Model for Characterizing a Donnan Dialysis Process. Industrial \& Engineering Chemistry Research 53: 6094-6102.

83. Simons, R. (1985) Water splitting in ion exchange membranes. Electrochimica Acta 30: $275-282$.

84. Rubinstein, I.; Zaltzman, B. (2000) Electro-osmotically induced convection at a permselective membrane. Physical Review E 62: 2238-2251. 
85. Rubinstein, S. M.; Manukyan, G.; Staicu, A.; Rubinstein, I.; Zaltzman, B.; Lammertink, R. G. H.; Mugele, F.; Wessling, M. (2008) Direct Observation of a Nonequilibrium Electro-Osmotic Instability. Physical Review Letters 101: 236101.

86. Tanaka, Y. (2010) Water dissociation reaction generated in an ion exchange membrane. Journal of Membrane Science 350: 347-360.

87. Sata, T.; Mine, K.; Higa, M. (1998) Change in permselectivity between sulfate and chloride ions through anion exchange membrane with hydrophilicity of the membrane. Journal of Membrane Science 141: 137-144.

88. Innocent, C.; Huguet, P.; Bribes, J. L.; Pourcelly, G.; Kameche, M. (2001) Characterisation of cation exchange membrane in hydro-organic media by electrochemistry and Raman spectroscopy. Physical Chemistry Chemical Physics 3: 1481-1485.

89. Chou, T.-J.; Tanioka, A. (1998) Ionic Behavior across Charged Membranes in Methanol-Water Solutions. 2. Ionic Mobility. Journal of Physical Chemistry B 102: 129-133.

90. Chou, T.-J.; Tanioka, A. (1998) Membrane Potential Across Charged Membranes in Organic Solutions. Journal of Physical Chemistry B 102: 7198-7202.

91. Pitzer, K. S., Activity coefficients in electrolyte solutions. 2nd ed.; CRC Press: Boca Raton, FL, 1991; p 542.

92. Ge, X.; Wang, X.; Zhang, M.; Seetharaman, S. (2007) Correlation and Prediction of Activity and Osmotic Coefficients of Aqueous Electrolytes at $298.15 \mathrm{~K}$ by the Modified TCPC Model. Journal of Chemical \& Engineering Data 52: 538-547.

93. Sarrazin, J. (1987) Resistance electrique de membranes echangeuses d'ions en solvant organique. Electrochimica Acta 32: 525-529.

94. Gebel, G.; Aldebert, P.; Pineri, M. (1993) Swelling study of perfluorosulphonated ionomer membranes. Polymer 34: 333-339.

95. Yeo, R. S.; Cheng, C. H. (1986) Swelling studies of perfluorinated ionomer membranes. Journal of Applied Polymer Science 32: 5733-5741.

96. Randová, A.; Hovorka, Š.; Izák, P.; Bartovská, L. (2008) Swelling of Nafion in methanol-water-inorganic salt ternary mixtures. Journal of Electroanalytical Chemistry 616: 117-121.

97. Walker, M.; Baumgärtner, K. M.; Kaiser, M.; Kerres, J.; Ullrich, A.; Räuchle, E. (1999) Proton-conducting polymers with reduced methanol permeation. Journal of Applied Polymer Science 74: 67-73.

98. Cabasso, I.; Liu, Z. Z. (1985) The permselectivity of ion-exchange membranes for non-electrolyte liquid mixtures. I. Separation of alcohol/water mixtures with nafion hollow fibers. Journal of Membrane Science 24: 101-119.

99. Ren, X.; Springer, T. E.; Gottesfeld, S. (2000) Water and methanol uptakes in nafion membranes and membrane effects on direct methanol cell performance. Journal of the Electrochemical Society 147: 92-98.

100. Skou, E.; Kauranen, P.; Hentschel, J. (1997) Water and methanol uptake in proton conducting Nafion ${ }^{\circledR}$ membranes. Solid State Ionics 97: 333-337.

101. Villaluenga, J. P. G.; Seoane, B.; Barragán, V. M.; Ruiz-Bauzá, C. (2003) Permeation of electrolyte water-methanol solutions through a Nafion membrane. Journal of Colloid and Interface Science 268: 476-481. 
102. Nandan, D.; Mohan, H.; Iyer, R. M. (1992) Methanol and water uptake, densities, equivalental volumes and thicknesses of several uni- and divalent ionic perfluorosulphonate exchange membranes (Nafion-117) and their methanol-water fractionation behaviour at 298 K. Journal of Membrane Science 71: 69-80.

103. Barragán, V. M.; Ruiz-Bauzá, C.; Villaluenga, J. P. G.; Seoane, B. (2004) Transport of methanol and water through Nafion membranes. Journal of Power Sources 130: 22-29.

104. Cabasso, I.; Liu, Z.-Z.; Makenzie, T. (1986) The permselectivity of ion-exchange membranes for non-electrolyte liquid mixtures. II. The effect of counterions (separation of alcohol/water mixtures with nafion membranes). Journal of Membrane Science 28: 109-122.

105. Cabasso, I.; Korngold, E.; Liu, Z.-Z. (1985) On the separation of alcohol/water mixtures by polyethylene ion exchange memberanes. Journal of Polymer Science: Polymer Letters Edition 23: 577-581.

106. Ethève, J.; Huguet, P.; Innocent, C.; Bribes, J. L.; Pourcelly, G. (2001) Electrochemical and Raman Spectroscopy Study of a Nafion Perfluorosulfonic Membrane in Organic Solvent-Water Mixtures. The Journal of Physical Chemistry B 105: 4151-4154.

107. Doyle, M.; Lewittes, M. E.; Roelofs, M. G.; Perusich, S. A.; Lowrey, R. E. (2001) Relationship between ionic conductivity of perfluorinated ionomeric membranes and nonaqueous solvent properties. Journal of Membrane Science 184: 257-273.

108. Barragán, V. M.; Villaluenga, J. P. G.; Godino, M. P.; Izquierdo-Gil, M. A.; RuizBauzá, C.; Seoane, B. (2008) Swelling and electro-osmotic properties of cation-exchange membranes with different structures in methanol-water media. Journal of Power Sources 185: 822-827.

109. Izquierdo-Gil, M. A.; Barragán, V. M.; Villaluenga, J. P. G.; Godino, M. P. (2012) Water uptake and salt transport through Nafion cation-exchange membranes with different thicknesses. Chemical Engineering Science 72: 1-9.

110. Tandon, R.; Pintauro, P. N. (2009) Solvent effects during multicomponent ion uptake into a Nafion cation-exchange membrane. Journal of Membrane Science 341: 21-29.

111. Tuan, L. X.; Buess-Herman, C. (2007) Study of water content and microheterogeneity of CMS cation exchange membrane. Chemical Physics Letters 434: 49-55.

112. Tuan, L. X.; Verbanck, M.; Buess-Herman, C.; Hurwitz, H. D. (2006) Properties of CMV cation exchange membranes in sulfuric acid media. Journal of Membrane Science 284: 67-78.

113. Iwai, Y.; Yamanishi, T. (2009) Thermal stability of ion-exchange Nafion N117CS membranes. Polymer Degradation and Stability 94: 679-687.

114. Galier, S.; Savignac, J.; Roux-de Balmann, H. (2013) Influence of the ionic composition on the diffusion mass transfer of saccharides through a cation-exchange membrane. Separation and Purification Technology 109: 1-8. 


\section{Figure Captions}

Figure 1 Physical configuration of a conventional electrodialysis stack operating on a solution of sodium chloride. $\mathrm{A}=$ Anion exchange membrane, $\mathrm{C}=$ Cation Exchange membrane.

Figure 2 An example of a current-voltage curve showing the relationship between the current density and the corresponding voltage drop over that membrane and its boundary layers (reproduced from Długołecki et al. (2010) with permission).

Figure 3 - Effect of glycerol concentration in the diluate stream of a model fermentation stillage on its rate of diffusion through Ionics CR6 1 CZL-386 and AR1 03 QZL-386 membranes (reproduced from Cheryan and Parekh (1995) with permission).

Figure 4 - Semilogarithmic plot of flux versus reciprocal of absolute temperature through a $\mathrm{Na}^{+}$counterion form of Nafion. $\square$ isopropanol; + water; o total. Activation Energy: 4.70, 4.91 and $4.68 \mathrm{kcal} / \mathrm{mol}$ for the total flux, water, and isopropanol, respectively. (Feed composition: isopropanol/water 89.2: $10.8 \% \mathrm{w} / \mathrm{w}$.) Reproduced from Cabasso et al. (1986) with permission.

Figure 5 Water content (a) and electrical resistance (b) of a Neosepta CMX membrane versus the composition of equilibrating solution ( $\mathrm{N}$-methylformamide in water) (reproduced from Innocent et al. (2001)).

Figure 6 - Volume based relative swelling of a range of commercial membranes in aqueous $0.1 \mathrm{M} \mathrm{Na}_{2} \mathrm{CO}_{3}$, in $70 \mathrm{wt} \%$ ethylene glycol mixed solvent and in $70 \mathrm{wt} \%$ ethylene glycol + $0.1 \mathrm{M} \mathrm{Na}_{2} \mathrm{CO}_{3}$ (reproduced from Gärtner et al. (2005) with permission).

Figure 7 - Wet mass (a) and conductivity (b) in a Neosepta CM2 membrane as a function of the vol\% methanol in a methanol/water solution (reproduced with permission from Chaabane et al., 2006).

Figure 8 - Total solvent uptake vs methanol volume fraction in Nafion 117 (reproduced with permission from Villaluenga et al., 2003)

Figure 9 - The effect of membrane swelling or solubility (open symbols) on the mean average diffusion coefficient (filled symbols) of water and isopropanol for a Nafion membrane in the $\mathrm{Na}+$ ionic form at $29^{\circ} \mathrm{C}$ with a feed solution as shown. The permeate side of the membrane is a vacuum $(10-100 \mathrm{~Pa})$. Data is taken from (Cabasso et al., 1986; Cabasso and Liu, 1985).

Figure 10 - Expansion area of a Nafion membrane versus the amount of solvent in the equilibrating solution: 4 THF, ( $) \mathrm{NMF},(\boldsymbol{\square})$ EG. Reproduced with permission from Ethève et al., (2001)

Figure 11 - Variation of the solute permeability through a Neosepta CMX membrane in saccharide/water systems versus the hydration number of the cation (reproduced from Galier et al. 2013 with permission). 


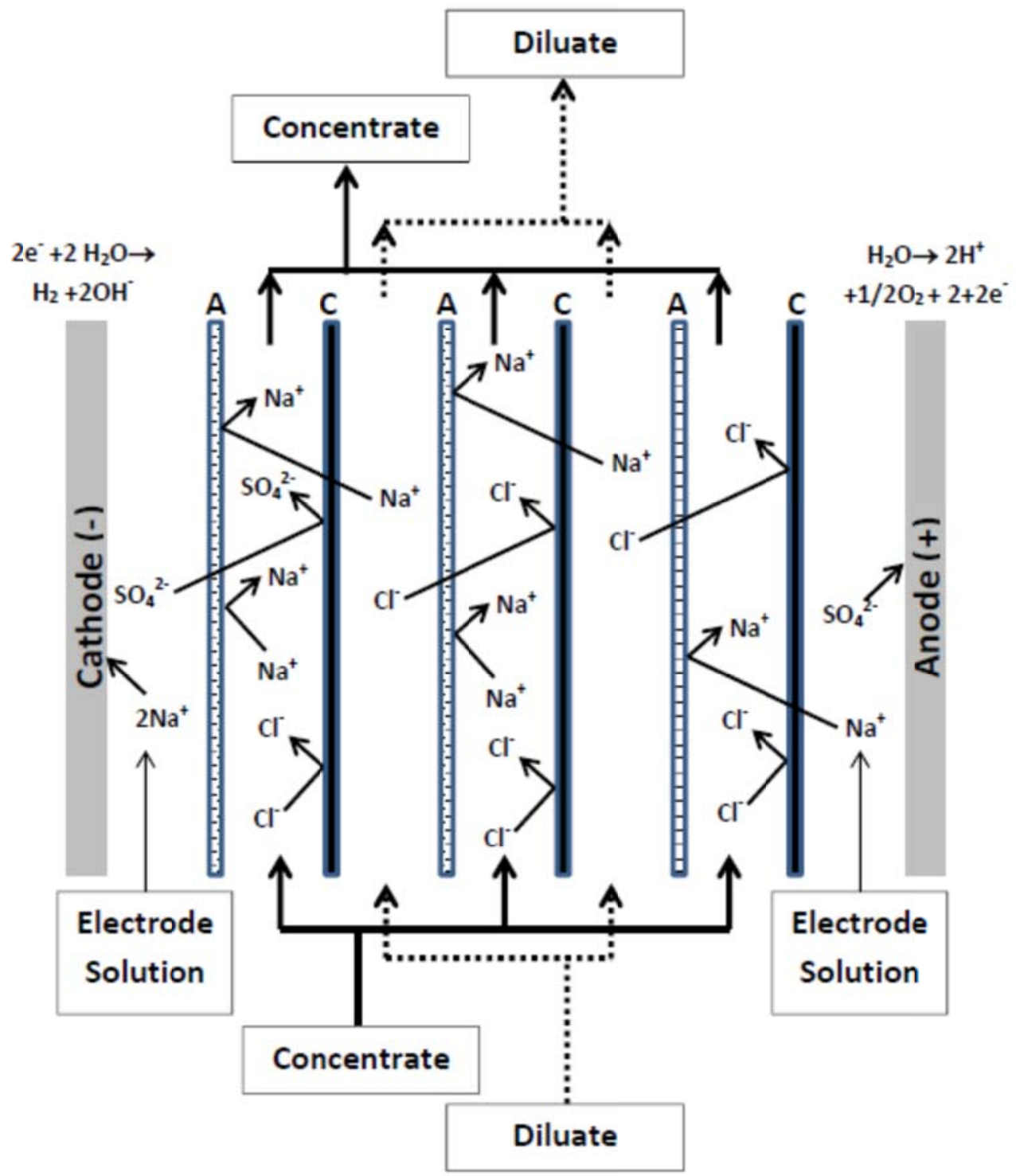

Figure 1 Physical configuration of a conventional electrodialysis stack operating on a solution of sodium chloride. $\mathrm{A}=$ Anion exchange membrane, $\mathrm{C}=$ Cation Exchange membrane. 


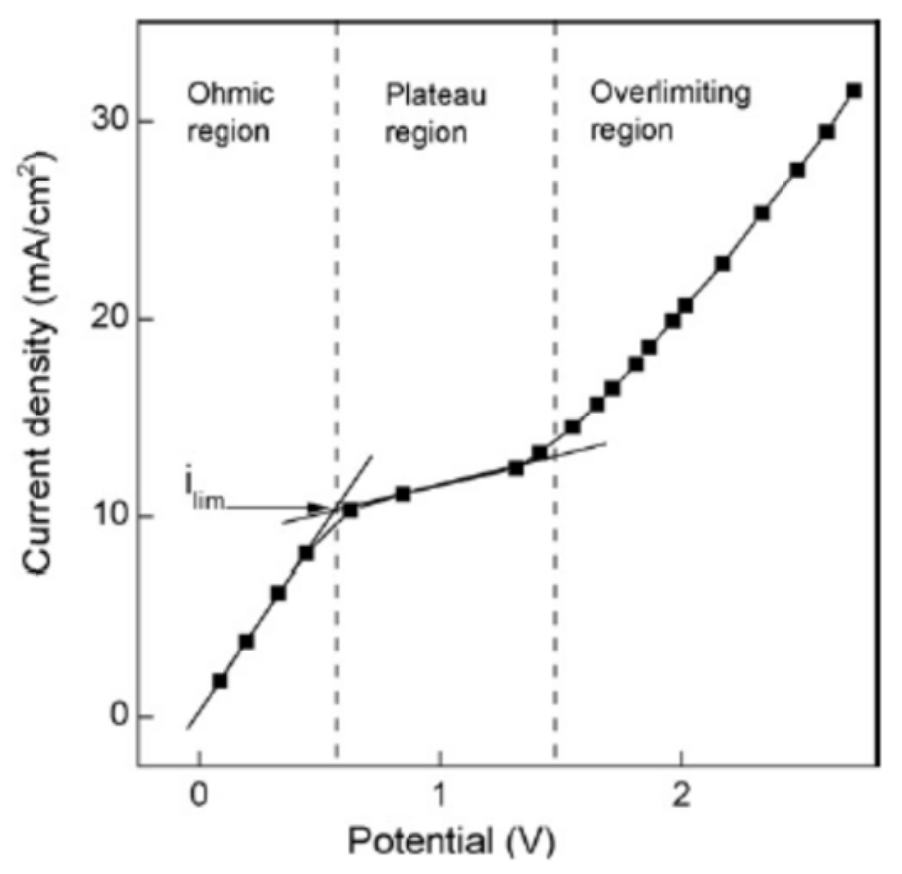

Figure 2. An example of a current-voltage curve showing the relationship between the current density and the corresponding voltage drop over that membrane and its boundary layers (reproduced from Długołecki et al. (2010)). 


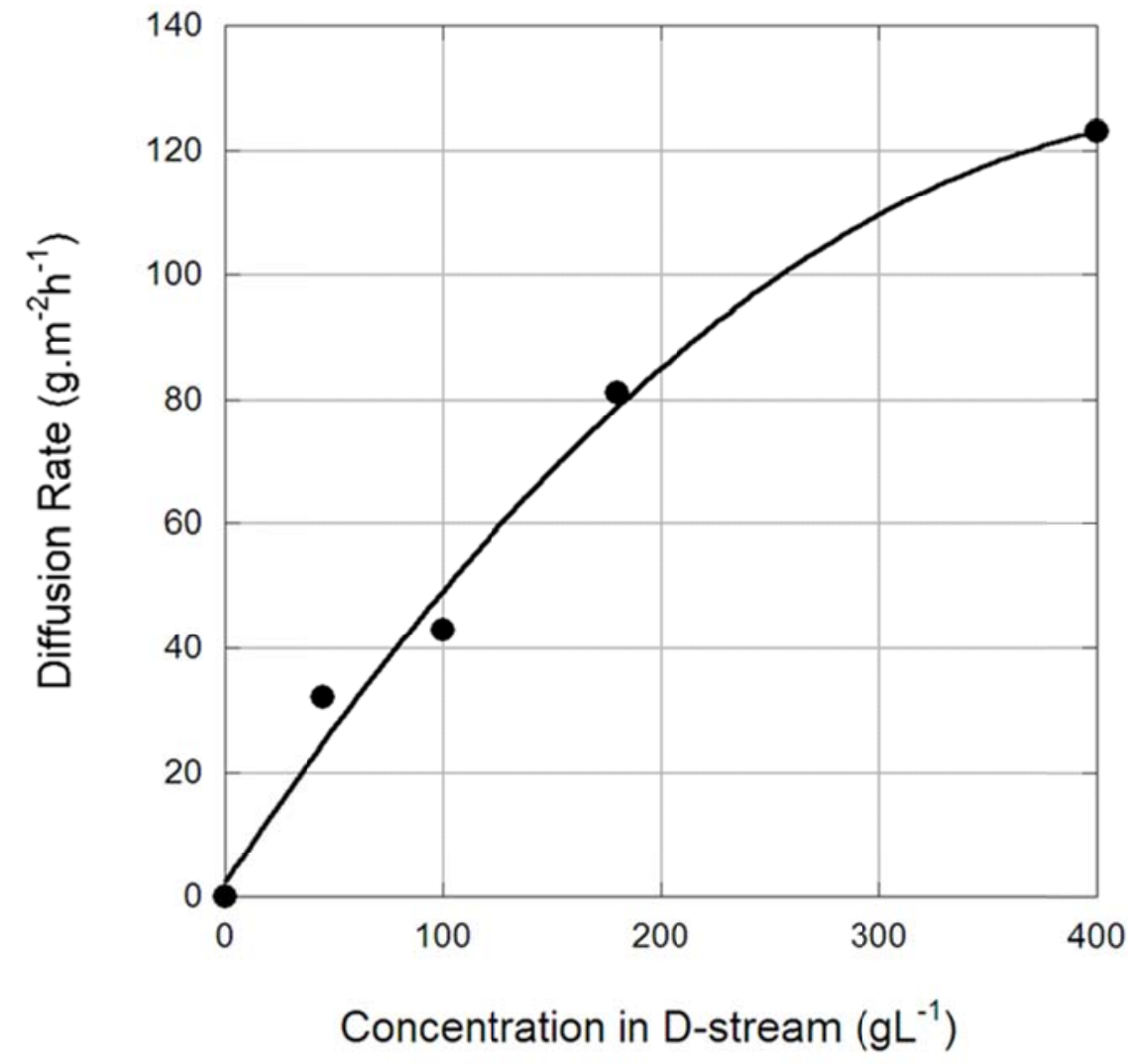

Figure 3 - Effect of glycerol concentration in the diluate stream of a model fermentation stillage on its rate of diffusion through Ionics CR6 1 CZL-386 and AR1 03 QZL-386 membranes (Cheryan and Parekh, 1995). 


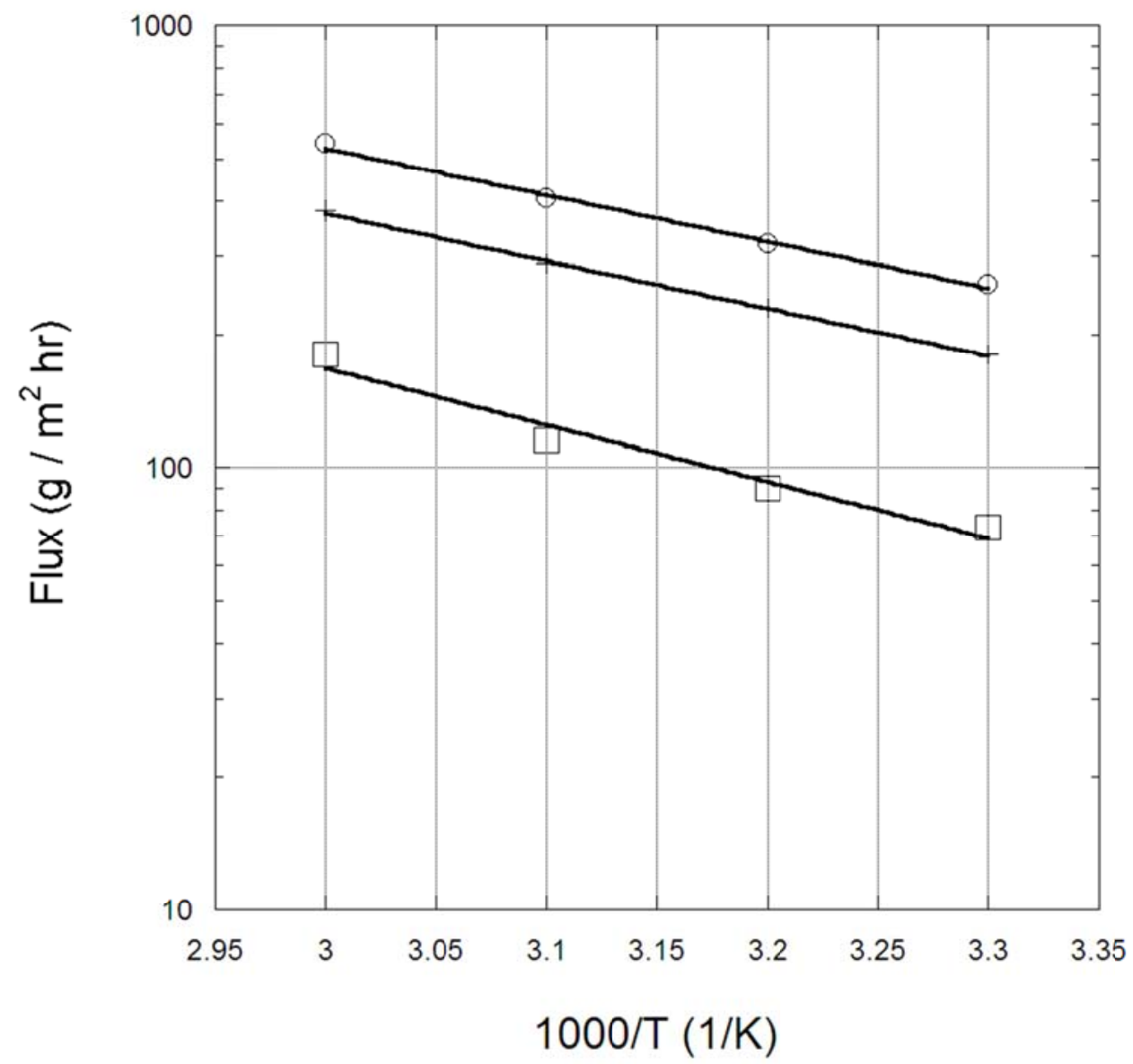

Figure 4 - Semilogarithmic plot of flux versus reciprocal of absolute temperature through a $\mathrm{Na}^{+}$counterion form of Nafion. $\square$ isopropanol; + water; o total. Activation Energy: 4.70, 4.91 and $4.68 \mathrm{kcal} / \mathrm{mol}$ for the total flux, water, and isopropanol, respectively. (Feed composition: isopropanol/water 89.2: 10.8 \%w/w.) Reproduced from Cabasso et al. (1986) 


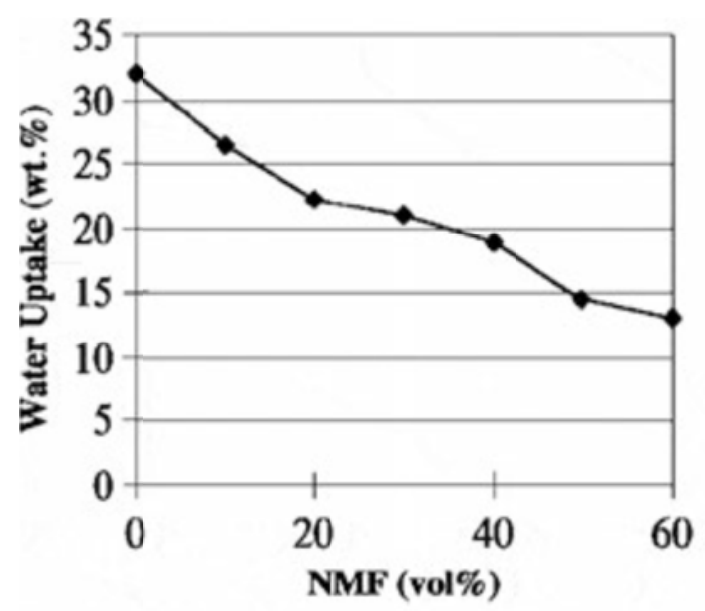

(a)

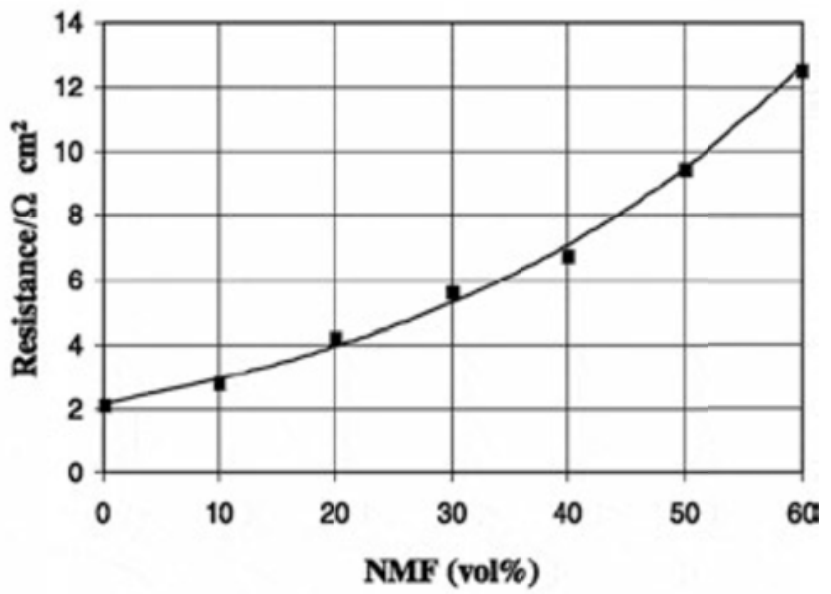

(b)

Figure 5 Water content (a) and electrical resistance (b) of a Neosepta CMX membrane versus the composition of equilibrating solution ( $\mathrm{N}$-methylformamide in water) (reproduced from Innocent et al. (2001)). 


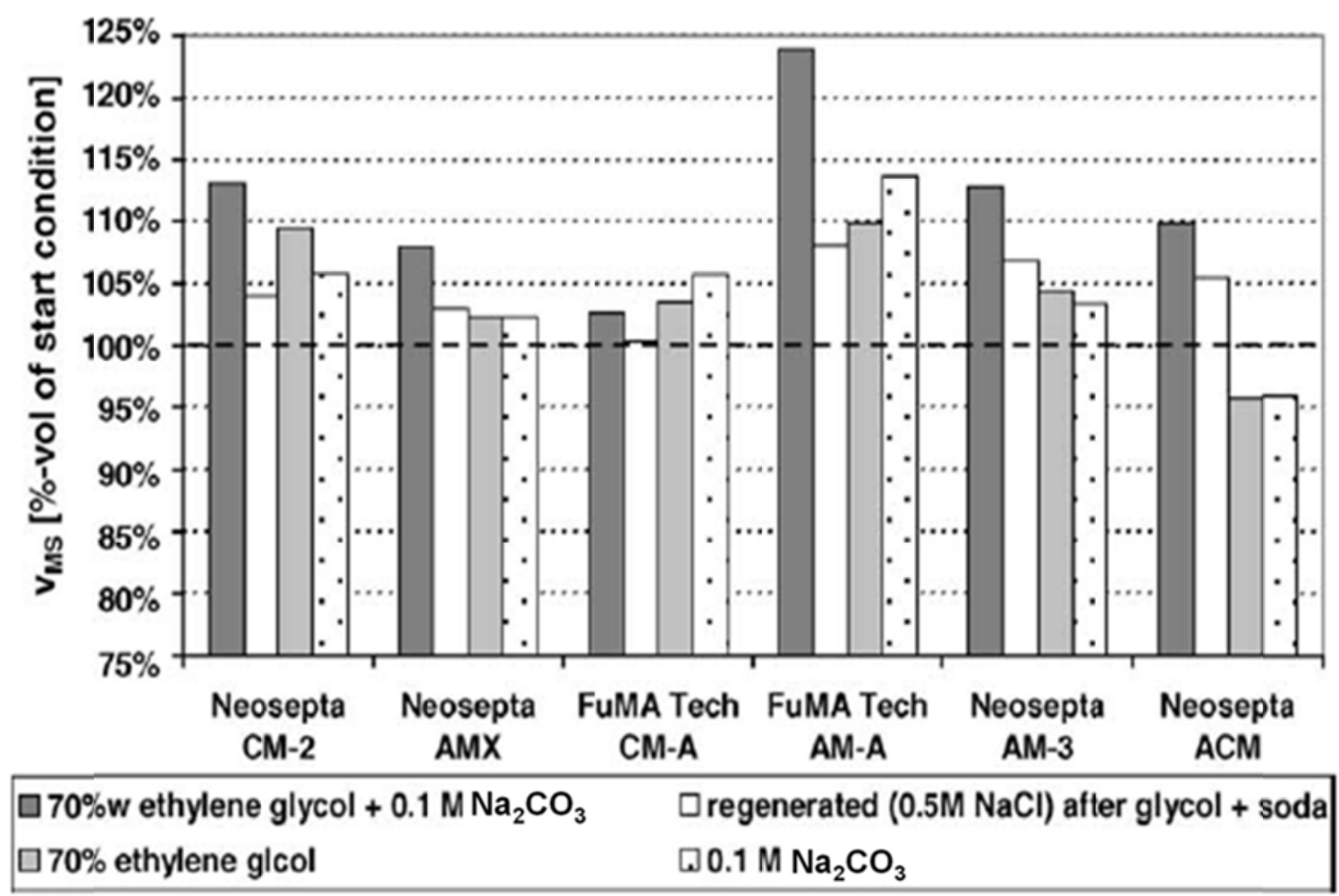

Figure 6 - Volume based relative swelling of a range of commercial membranes in aqueous $0.1 \mathrm{M} \mathrm{Na}_{2} \mathrm{CO}_{3}$, in $70 \mathrm{wt} \%$ ethylene glycol mixed solvent and in $70 \mathrm{wt} \%$ ethylene glycol + $0.1 \mathrm{M} \mathrm{Na} 2 \mathrm{CO}_{3}$ (reproduced from Gärtner et al. (2005) with permission). 

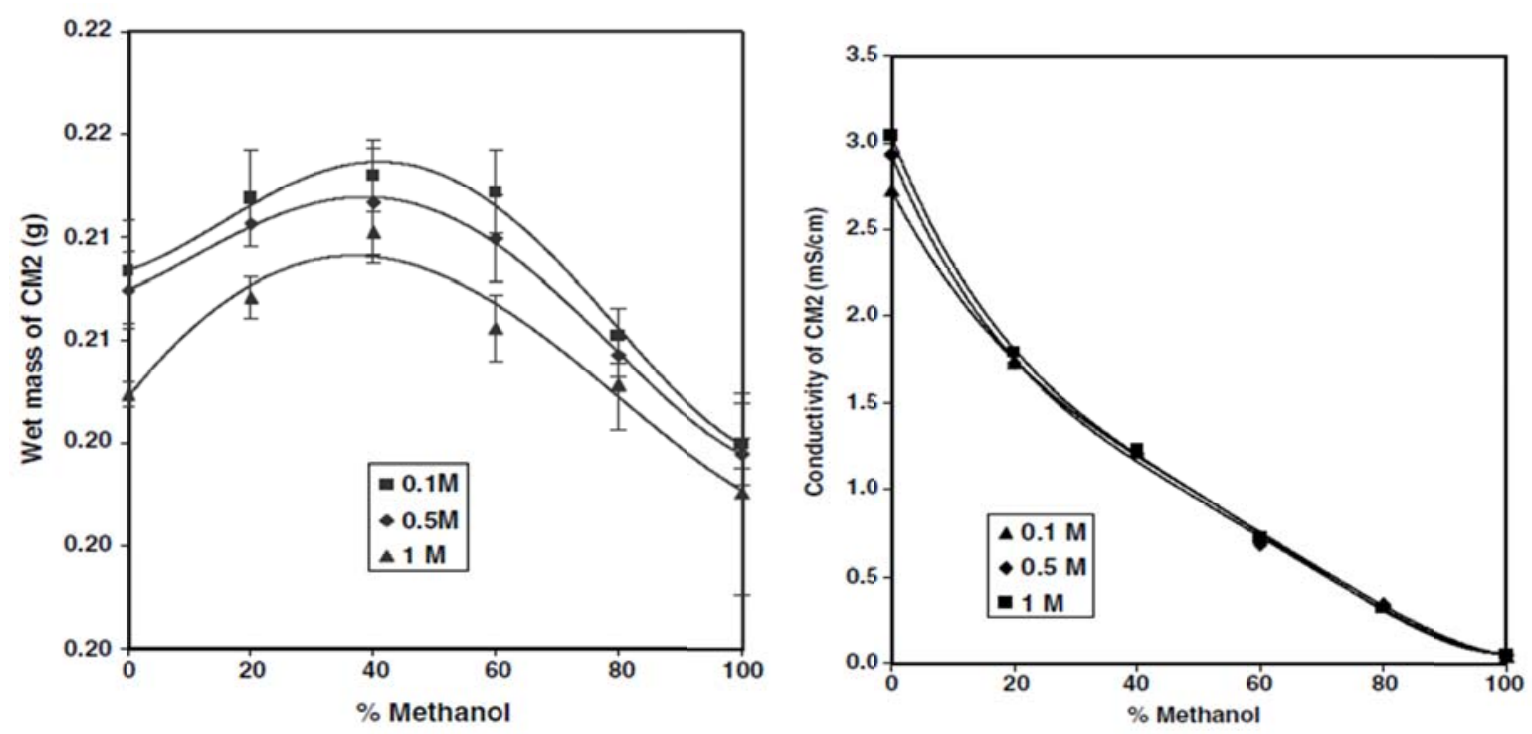

Figure 7 - Wet mass (a) and conductivity (b) in a Neosepta CM2 membrane as a function of the vol\% methanol in a methanol/water solution (reproduced with permission from Chaabane et al., 2006). 


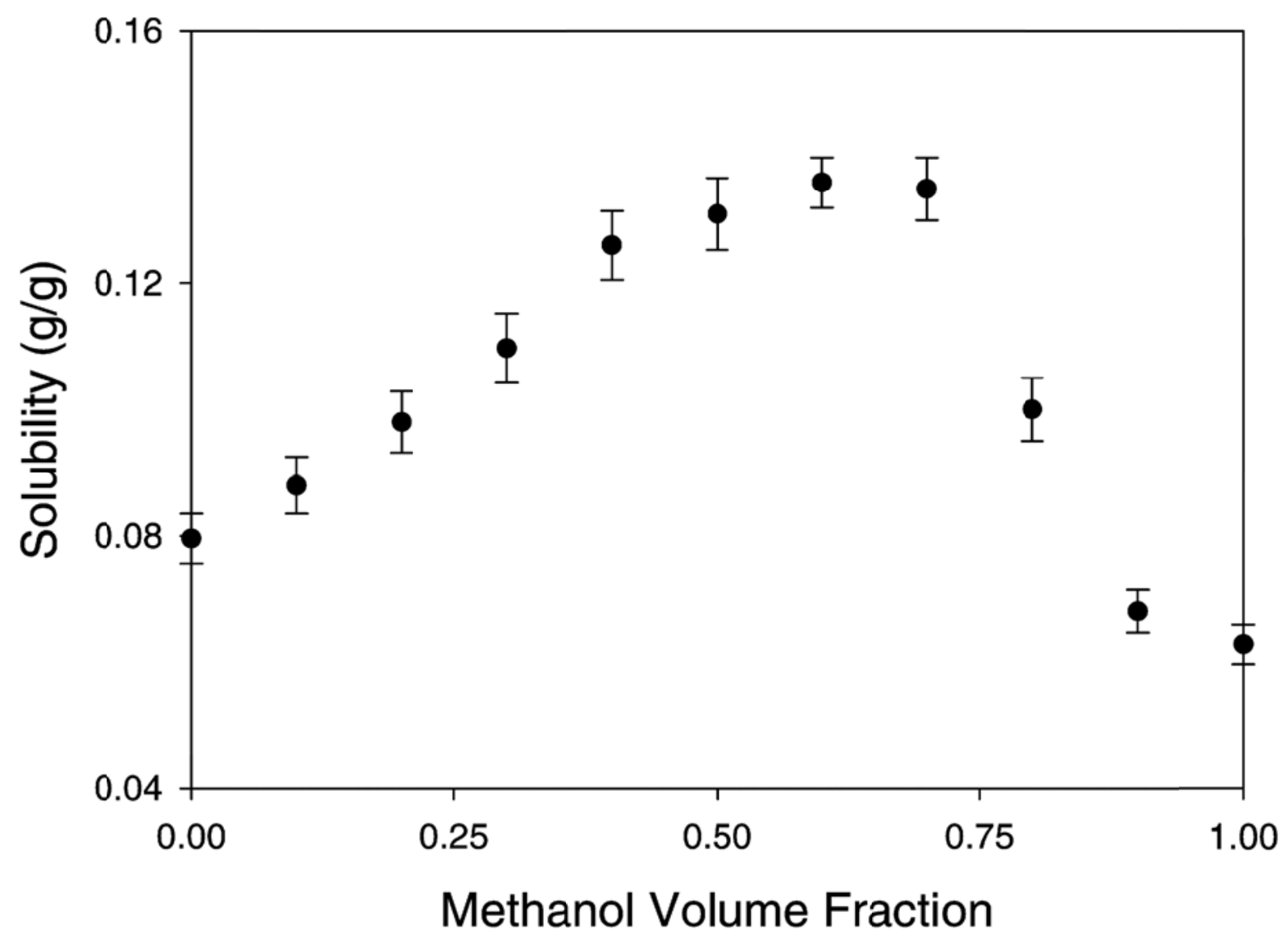

Figure 8 - Total solvent uptake vs methanol volume fraction in Nafion 117 (reproduced with permission from Villaluenga et al., 2003) 


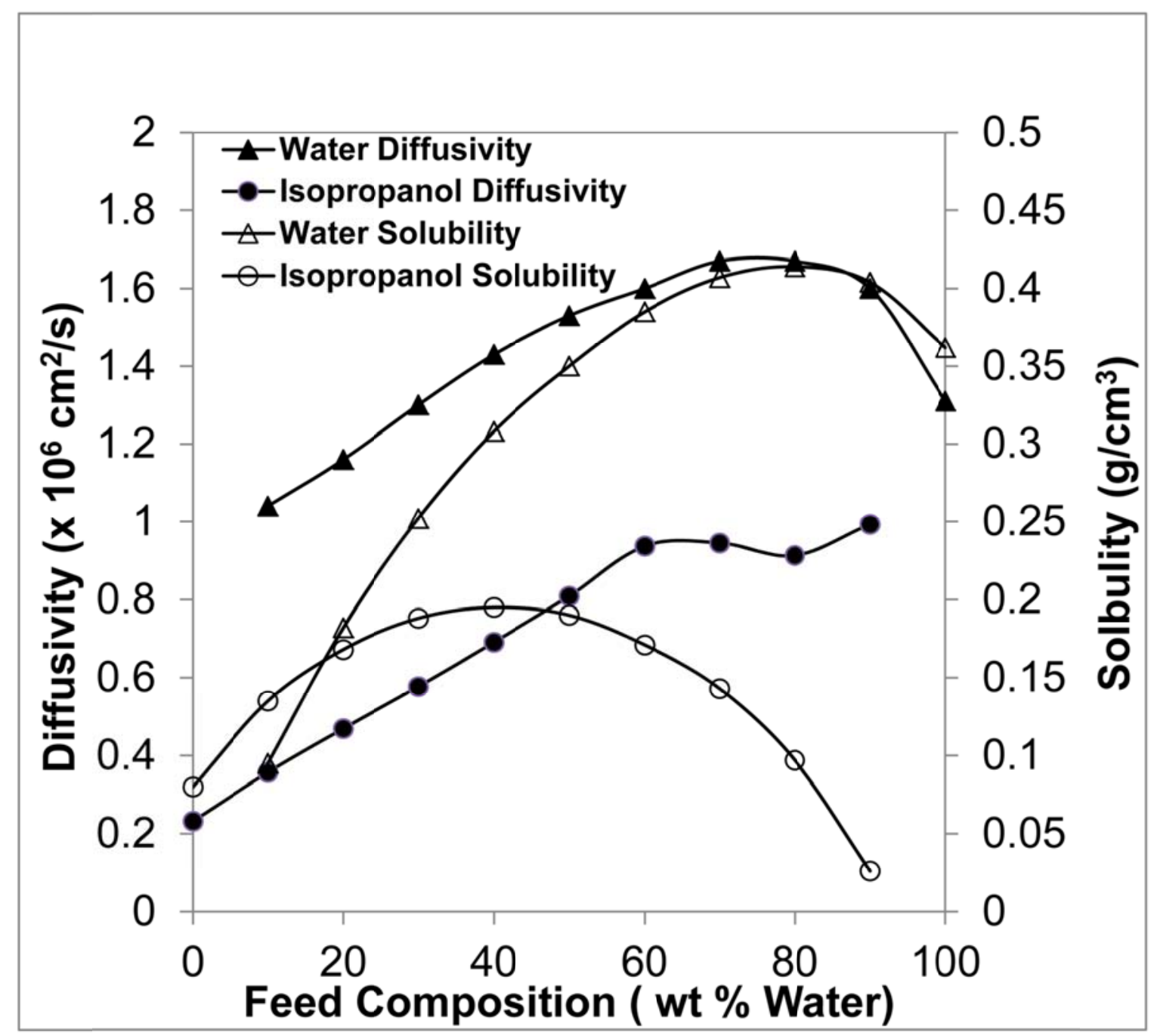

Figure 9 - The effect of membrane swelling or solubility (open symbols) on the mean average diffusion coefficient (filled symbols) of water and isopropanol for a Nafion membrane in the $\mathrm{Na}^{+}$ionic form at $29^{\circ} \mathrm{C}$ with a feed solution as shown. The permeate side of the membrane is a vacuum $(10-100 \mathrm{~Pa})$. Data is taken from (Cabasso et al., 1986; Cabasso and Liu, 1985). 


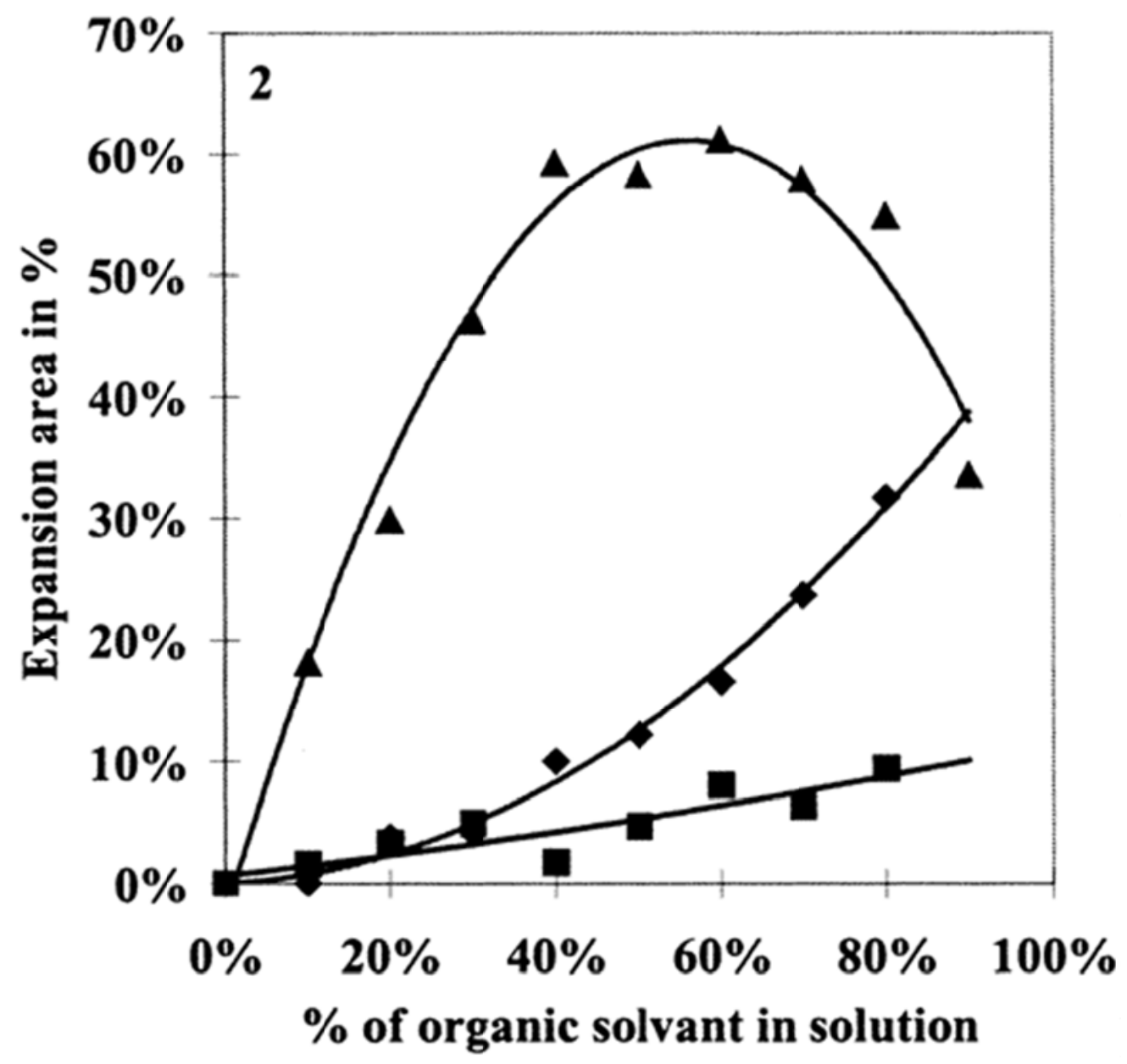

Figure 10 - Expansion area of a Nafion membrane versus the amount of solvent in the equilibrating solution: $(\boldsymbol{)}) \mathrm{THF},(\bullet) \mathrm{NMF},(\boldsymbol{\nabla})$ EG. Reproduced with permission from Ethève et al., (2001) 


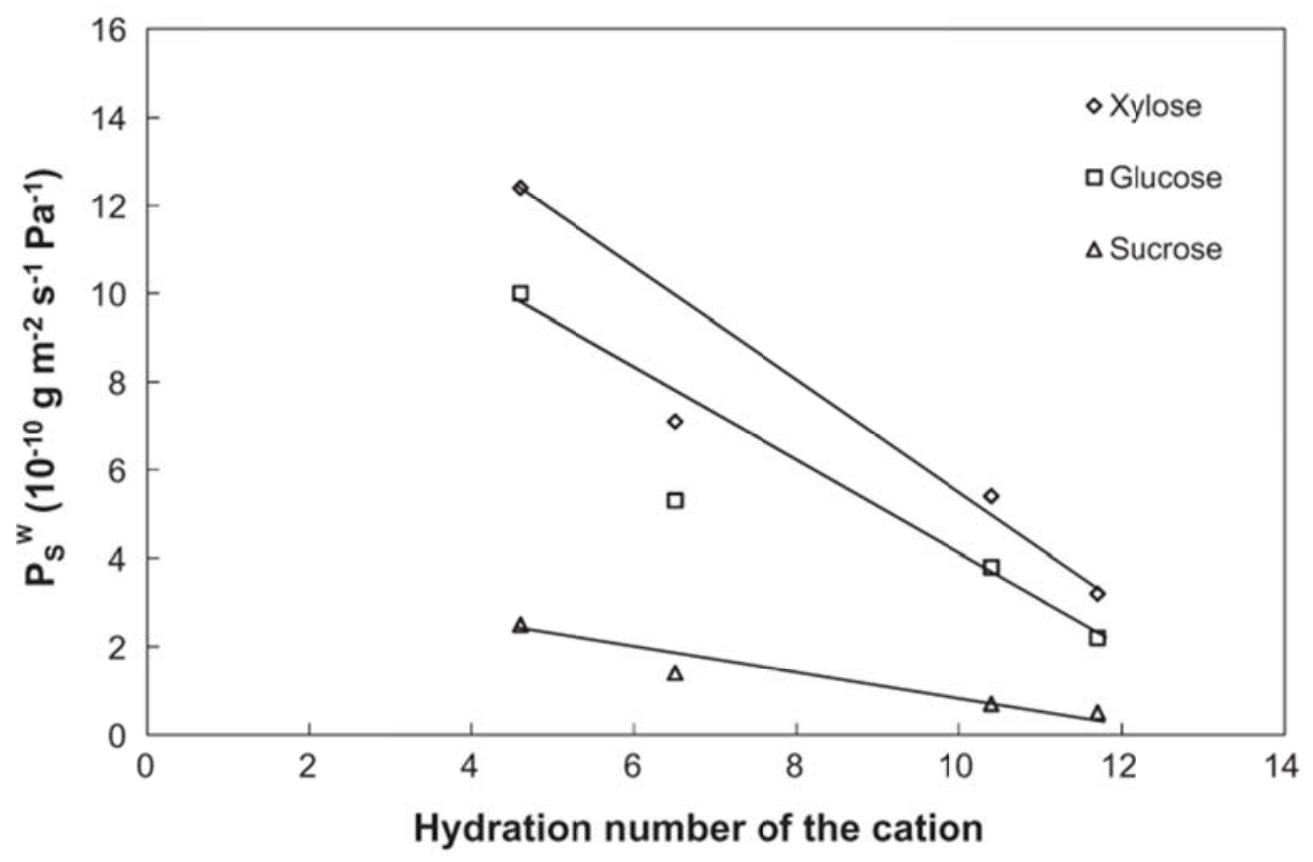

Figure 11 - Variation of the solute permeability through a Neosepta CMX membrane in saccharide/water systems versus the hydration number of the cation (reproduced from Galier et al. 2013 with permission). 


\section{University Library}

\section{- M M N E R VA A gateway to Melbourne's research publications}

Minerva Access is the Institutional Repository of The University of Melbourne

Author/s:

Kentish, SE;KLOESTER, E;Stevens, GW;Scholes, CA;Dumee, L

Title:

Electrodialysis in Aqueous-Organic Mixtures

Date:

2015

Citation:

Kentish, S. E., KLOESTER, E., Stevens, G. W., Scholes, C. A. \& Dumee, L. (2015).

Electrodialysis in Aqueous-Organic Mixtures. Separation and Purification Reviews, 44 (4), pp.269-282. https://doi.org/10.1080/15422119.2014.941111.

Persistent Link:

http://hdl.handle.net/11343/43787 